Article

\title{
Achieving Sustainable Urban Development with an Ageing Population: An "Age-Friendly City and Community" Approach
}

\author{
Jianbo Han ${ }^{1, *}$, Edwin Hon Wan Chan ${ }^{1}\left(0\right.$, Queena Kun Qian ${ }^{2}$ and Esther Hiu Kwan Yung ${ }^{1}$ \\ 1 Department of Building and Real Estate, The Hong Kong Polytechnic University, Hong Kong 999077, China; \\ edwin.chan@polyu.edu.hk (E.H.W.C.); esther.yung@polyu.edu.hk (E.H.K.Y.) \\ 2 Faculty of Architecture and Built Environment, Delft University of Technology, 2628 Delft, The Netherlands; \\ k.Qian@tudelft.nl \\ * Correspondence: blacksunset1116@hotmail.com
}

check for

updates

Citation: Han, J.; Chan, E.H.W.; Qian, Q.K.; Yung, E.H.K. Achieving Sustainable Urban Development with an Ageing Population: An "AgeFriendly City and Community" Approach. Sustainability 2021, 13, 8614. https://doi.org/10.3390/ su13158614

Academic Editors: Mary J. Thornbush and Manuel Duarte Pinheiro

Received: 8 April 2021

Accepted: 29 July 2021

Published: 2 August 2021

Publisher's Note: MDPI stays neutral with regard to jurisdictional claims in published maps and institutional affiliations.

Copyright: (c) 2021 by the authors. Licensee MDPI, Basel, Switzerland. This article is an open access article distributed under the terms and conditions of the Creative Commons Attribution (CC BY) license (https:// creativecommons.org/licenses/by/ $4.0 /)$.

\begin{abstract}
The ageing population tends to be seen as a burden of cities' future development. Thus, the public funds for older residents' wellbeing are at risk of being cut back under the economic austerity due to the prevalent neoliberalism policy atmosphere. However, some cities set good examples to turn their older citizens into active contributors to sustainable urban development (SUD) by developing age-friendly cities and communities (AFCC). Taking Hong Kong as an example, this study aims to raise a strategy for policymakers, especially at the municipal level, to incorporate the concept of AFCC in SUD. Data were retrieved for our analysis from a published report of the Hong Kong Public Policy Research Fund project. A total of 15 AFCC and SUD policy factors were identified by using factor analysis. The correlations between these policy factors were evaluated and visualised in a synergetic effect network. According to the network, this study indicates that developing the silver hair market can be a suitable entry point to realise SUD by adopting an AFCC development. Isolation prevention, social sustainability and low-energy-consumption development are the supportive policy factors for the silver hair market. Specifically, respect, discrimination prevention, communication and information, age-friendly facilities, environmental safety and public transportation accessibility are five AFCC policy factors incorporated in the policy integration to enhance older residents' wellbeing further. This study is an innovative attempt to develop a comprehensive model for the synergy between sustainable urban development and an age-friendly city and community using a correlation network. This study also provides a reference for other city governments to respond to population ageing positively.
\end{abstract}

Keywords: sustainable development; age-friendly development; policy integration; population ageing; urban economy

\section{Introduction}

Population ageing is a global trend that will change the demographic structure dramatically, and Hong Kong, as a densely populated city, is no exception. According to the latest projection by the Hong Kong Census and Statistics Department, Hong Kong citizens aged above 65 will account for $33.3 \%$ of the city's whole population in 2039 [1]. This demographic trend has caused many worries about the future development of cities as population ageing tends to be linked with the workforce shortage and burden of social security [2]. According to the labour force projection, due to population ageing, Hong Kong will see a drop in local workforce supply with an average annual rate of $0.2 \%$ from 2017 to 2027 [3]. Meanwhile, it is estimated that about one-fifth of recurrent government expenditure will be invested into social security, health care services and long-term care services for older people in the 2021-2022 financial year [4]. This considerable investment can be challenging for Hong Kong and many other similar economies because of the funding austerity in the neoliberal policy atmosphere $[5,6]$. Therefore, to justify investing in 
older citizens' wellbeing, it is necessary to ask how the expenditure can be paid back in a long-term sustainable urban development (SUD).

Recently, opinions about the implication of population ageing on SUD have turned more positive. Besides the challenges, population ageing also brings opportunities for the environmental, economic and social pillars of SUD [7]. Policymakers in many world metropolitans, such as Hong Kong [8], London [9] and New York [10], acknowledge older people's contribution to society and urban development. These cities have holistic consideration for older people in the cities' long-term development strategies [11-13] to enhance SUD by the silver hair dividend. This kind of pioneering policy innovation can set good examples for many cities to mitigate the negative impact of funding austerity on policymaking for older people.

Active ageing and age-friendly cities and communities (AFCC) are two underlying principles that facilitate policymakers considering the aged population as a resource for SUD. Launched by the World Health Organisation (WHO) in 2002 [14], the concept of active ageing indicates that older people can become continuous contributors to society with better health, security and participation [15]. Furthermore, previous studies have proved that older people are capable of revitalising the street commercial [16], retaining the local culture capital [17], participating in urban agriculture [18] and contributing to economic activities [19]. From this perspective, older people can be seen as a powerful impetus in future urban development. Therefore, developing cities with the principle of active ageing can be regarded as a feasible measure to facilitate SUD in the face of inevitable population ageing.

To reflect the active ageing concept in urban development, the WHO developed a guideline for AFCC in 2007. AFCC is a concept that contains a series of "services, policies and structures" to ensure older people have access to suitable urban environments and facilities to realise their active ageing [20]. Policy is one of the core components of AFCC development. According to the guideline, the AFCC policies should cover eight domains in both built and social environment aspects [21]. These eight domains include (1) outdoor space and buildings, (2) transportation, (3) housing, (4) social participation, (5) respect and social inclusion, (6) civic participation and employment, (7) communication and information and (8) community support and health services [20]. As a derivative of active ageing, the AFCC guideline gives a more precise direction for city governments to transform older residents into contributors to future urban development. Thus, incorporating AFCC in SUD is advocated by previous studies to realise the co-benefits of both policy agendas [22,23].

Taking Hong Kong as an example of a densely populated city, this study aims to raise a strategy for policymakers, especially at the municipal level, to incorporate AFCC in SUD by answering three research questions:

(1) What should be the entry points of the policy integration?

(2) How to address the issues identified in research question (1)?

(3) By achieving SUD with the integrated policies established by (1) and (2), how to incorporate more AFCC factors to improve the wellbeing for older residents?

Firstly, this study identified the SUD and AFCC policy factors. A secondary dataset was retrieved for our intensive analysis from a Hong Kong Public Policy Research (PPR) Funding project named the "Sustainable Planning Criteria (SPC) for Age-Friendly Precincts (AFP) in New Development Areas (NDAs) of Hong Kong" [24]. The dataset incorporates 772 Hong Kong residents' perceived importance of a list of SUD and AFCC criteria collected by a street survey in 2014. Factor analysis was used to reduce the dimension of the criteria list and identify 15 representative policy factors of SUD and AFCC. Based on the theory of policy integration, an effective integration relies on the synergistic relationship between two policies $[25,26]$. Thus, the second step of this study was to evaluate the synergetic relationship by understanding the correlations between SUD and AFCC representative factors. Lastly, the synergistic effects between SUD and AFCC were further visualised in a network to reflect the correlation coefficients among these representative policy factors. The three research questions were answered by referring to the synergy network. For the first 
question, the nodes acting as the central linkages between SUD and AFCC were identified as the entry points, or leverage points [27], of the policy integration. The centrality was judged by the degree of the nodes in the network. For the second question, the nodes directly linking to the entry points were identified as the supportive factors. For the third question, the AFCC nodes not directly linking to the entry points in the network can be developed to enhance older people's wellbeing further.

This study can help city governments positively react to population ageing in their city's future development by providing an explicit strategy for the policy integration of AFCC and SUD. In addition, the quantitative approach, especially the construction of correlation network, in this study can be an efficient and objective supplement to the qualitative approaches that are commonly used in policy integration research (e.g., focus groups and roundtables). Lastly, Hong Kong as a case study of AFCC development in more detail, all the 18 districts of the city are accredited in the WHO's Global Network for Age-Friendly Cities and Communities (GNAFCC). As the GNAFCC is yet to expand, this study provides an example for the potential participating cities to develop AFCC in line with their long-term urban development.

In the following sections, the "Literature Review" contains three topics, including (1) the policy integration theory, (2) interaction between SUD and AFCC and (3) characteristics of Hong Kong's AFCC policies as highlighted by a comparative review. In the "Methodology" section, the dataset and factor analysis methods are described in detail. The "Results" section presents the results of the factor analysis and the visualised correlation network of the identified factors. The "Discussion" section explains the answers to the three research questions according to the correlation network. Finally, the "Conclusions" section summarises this study, while limitations and future research directions are also raised.

\section{Literature Review}

\subsection{Policy Integration: Inter-Sectoral Synergy}

Policy integration is the underlying theory of this study. The definition of policy integration varies between studies because of different research focuses [27-33]. However, inter-sectoral coordination is the common theme of these definitions. Inter-sectoral policy integration can be achieved by three means, including coordination, harmonisation and prioritisation. Coordination mitigates the contradiction between different domains. Harmonisation facilities co-benefits between different domains. On the contrary, prioritisation prioritises a particular domain over the others [34,35]. This study focuses on coordination and harmonisation to explore the synergy between SUD and AFCC. For coordination, this study tries to correct the negative attitude of SUD towards population ageing. In AFCC, older citizens will not be regarded as an economic burden for SUD, but as a new impetus. For harmonisation, this study identifies the correlations between AFCC and SUD factors and shows how these two sectors can complement each other in urban development. Thus, in the next part of the literature review, some potential correlations between AFCC and SUD will be identified from previous related studies.

\subsection{Age-Friendly and Sustainable Development-An Integration Perspective}

SUD can interact with a wide range of other urban policy agendas [36]. This part of the review focuses of the interaction between SUD and AFCC. A search for the themes of sustainability and age-friendly was performed in the Web of Science to explore the potential correlations between SUD and AFCC. Among the 22 returned papers, 11 papers used the term sustainability to represent SUD. Thus, this part of the review summarises these 11 papers.

According to previous studies, AFCC relates to the general concept of SUD. Khan and Zaman identified ten aspects of SUD: urban form, social aspect, cultural aspect, political aspect, economic aspect, environmental aspect, technological aspect, governance, transport and mobility and safety and security. They reviewed three broadly cited AFCC stud- 
ies [21,22,37] and showed that AFCC are related to all the ten aspects of SUD [38]. Previous studies also found the relationship between AFCC and community sustainability. Lehning and Greenfield suggested that AFCC should be incorporated in building sustainable communities [39]. Similarly, Siew suggested integrating age-friendly consideration into sustainability reporting tools to improve the community developers' awareness and the intention to develop AFCC [40]. Among different aspects of AFCC, age-friendly facilities are proved to be an essential factor related to SUD. Liu et al. [41] stressed that providing enough community-based care facilities has been the main task for Xi'an's SUD. Zaman and Thornton found that building an age-friendly environment and facilities can facilitate Unley's SUD goal by fulfilling citizens' dignity and equality in a healthy environment [42].

The correlation between environmental sustainability and AFCC lies in two aspects, the liveable environment, and activities to promote environmental protection. For a liveable environment, Fabrizio et al. [43] studied a net-zero-energy building project in Ladispoli. They found the project also brought about improved access to greenery, enhancing older people's physical and psychological wellbeing. Moreover, an Alzheimer Garden was established to provide a specialised zone for this vulnerable aged group. In a Romanian national study, Ivan, Beu and van Hoof [44] found that using intelligent technologies to enhance energy-saving also improves the age-friendliness of residential houses. The Ladispoli and Romanian cases are also echoed in a Hong Kong study. Qian et al. [45] found that respect, communication and information and community and health services positively associate with environmental sustainability. For activities to promote environmental protection, Clark [46] studied an AFCC project in Philadelphia called GenPhilly. The study indicates that older residents are interested in participatory social events about environmental sustainability.

Economic sustainability is seldom mentioned to be related to AFCC in previous studies. The only reference found from Qian et al. defines economic sustainability as using existing resources optimally to create continuous economic value and growth. According to their Hong Kong case, social/civic participation and employment and community and health services positively associate with economic sustainability [45].

According to Liu et al.'s paper [47], two dimensions incorporated in social sustainability relate to AFCC: (1) needs satisfaction and wellbeing and (2) social justice and equity. Matei and Saghin [48] found that the combined support from government policy and local initiatives for residential care centres can improve older people's rights to social sustainability in Romania. The Hong Kong case from Qian et al. shows that social/civic participation and employment, communication and information and community and health services positively relate to social sustainability [45].

Besides the commonly referred three pillars of SUD, To and Chong [17] also raised the attention to cultural sustainability in AFCC studies. Cultural sustainability means preserving regional cultural identities and values. The study, using a Tokyo case, shows that older residents and AFCC can facilitate regional cultural sustainability. Moreover, such cultural sustainability is also the driver, catalyst and enabler of the three main pillars of SUD.

The review above reveals a research gap in the relationship between economic sustainability and AFCC. It is necessary to identify the correlation between economic sustainability and AFCC because it can avoid putting AFCC as an economic burden for SUD. Therefore, this study proposed the first hypothesis as follows:

Hypothesis 1. (H1). Some AFCC factors have correlations with economic sustainability.

Another highlight of the above review is the frequent appearance of community services and related facilities. The services and facilities are related to both the general SUD and the three sustainability pillars. It may indicate the critical role of community service and related facilities in the policy integration of SUD and AFCC. Thus, the second hypothesis of this study was formed as below. 
Hypothesis 2. (H2). Community services and related facilities can be the entry point of the policy integration of SUD and AFCC.

Lastly, some other AFCC factors also relate to one or two SUD factors. According to the review, these AFCC factors are identified as outdoor space and buildings, housing, social participation, respect and social inclusion, civic participation and employment and communication and information. Therefore, we formed the third hypothesis of this study as below.

Hypothesis 3. (H3). Outdoor space and buildings, housing, social participation, respect and social inclusion, civic participation and employment and communication and information can be the supportive factors in the policy integration of SUD and AFCC.

The three hypotheses form a hypothetical model for policy integration to answer the three research questions. In the model, community support and health services are the entry point to facilitate the policy integration of SUD and AFCC. At the same time, outdoor space and buildings, housing, social participation, respect and social inclusion, civic participation and employment and communication and information are the six AFCC factors that can support the policy integration. Finally, transportation is the only AFCC factor to enhance older residents' wellbeing further.

\subsection{Hong Kong Age-Friendly Policy: A Comparative Review}

As mentioned above, this study needs to correct the negative attitude of SUD towards population ageing. Meanwhile, policies are one of the primary sources that the stereotypes of older people come from [49]. Thus, this study makes a policy comparison of AFCC between Hong Kong and some other similar densely populated cities in the world. The comparative review indicates how exemplar age-friendly cities integrate AFCC in their long-term urban development strategies. The review also summarises the strengths and weaknesses of Hong Kong's AFCC policies.

According to Hong Kong's characteristics and the topic of AFCC, this study set four criteria to choose the cities for this comparative review: (1) being a global metropolitan [5], (2) being a member of the Global Network for Age-friendly Cities and Communities (GNAFCC) [50], and (3) documents to be reviewed mainly written in English and Chinese (for Hong Kong's public documents).

An initial city list was retrieved from The World According to GaWC 2020, which shows a rank of global metropolitans [51]. As Hong Kong is ranked third, the top nine cities, Alpha ++ and Alpha + cities, were put in the initial list. According to the other selection criteria, London, New York, and Singapore were chosen for the comparative review.

\subsubsection{London}

London joined the GNAFCC in 2018 [52]. AFCC is one of the issues in the city development strategy of Inclusive London [53]. The term age-friendly does not appear in the policy text of Inclusive London. However, in the policy, some inactive lifestyle of London's older residents is stated by citing "An Age Friendly City: How far has London come?", which is a progress report of London's AFCC development from 2007 to 2016 [12,52,54]. Although there is no specific section for older people in the policy, the authority released a special readers' guide to highlight the content related to older people [55]. The readers' guide covers all the eight domains of AFCC. The city's long-term development strategy is The London Plan published in 2021, which indicates the development plan for the next 20-25 years. Although the term age-friendly does not appear in the plan, Inclusive London is incorporated in the plan, bringing AFCC into the city's future development [56].

According to a search on the government website, Greater London Authority has no specific policies for AFCC, and AFCC seldom appears in the policy text. However, the government and policymakers incorporate AFCC considerations in various policies and 
programmes of the city. Table 1 summarises the results of a search for age-friendly on the government website.

Table 1. London AFCC policies and programmes.

\begin{tabular}{|c|c|}
\hline Domain & Policies and Programmes \\
\hline All eight domains & $\begin{array}{l}\text { Inclusive London: The Mayor's Equality, } \\
\text { Diversity and Inclusion Strategy }[12,55]\end{array}$ \\
\hline Civic participation and employment & Talk London $[53,57]$ \\
\hline Transportation & Freedom Pass [58] \\
\hline Transportation & 60+ London Oyster photocard [59] \\
\hline $\begin{array}{c}\text { Outdoor space and buildings } \\
\text { Housing } \\
\text { Social participation } \\
\text { Respect and social inclusion } \\
\text { Civic participation and employment } \\
\text { Community support and health services }\end{array}$ & Get Moving [60] \\
\hline $\begin{array}{c}\text { Social participation } \\
\text { Respect and social inclusion } \\
\text { Communication and information } \\
\text { Community support and health services }\end{array}$ & Mi Wi-Fi [61] \\
\hline $\begin{array}{c}\text { Outdoor space and buildings } \\
\text { Housing } \\
\text { Social participation } \\
\text { Respect and social inclusion } \\
\text { Community support and health services }\end{array}$ & The London Plan [56] \\
\hline $\begin{array}{l}\text { Civic participation and employment } \\
\text { Community support and health services }\end{array}$ & Team London [62] \\
\hline $\begin{array}{l}\text { Outdoor space and buildings } \\
\text { Social participation } \\
\text { Respect and social inclusion } \\
\text { Community support and health services }\end{array}$ & Community Spaces at Risk Fund [63] \\
\hline Respect and social inclusion & Equality and fairness workplan 2018-19 [64] \\
\hline
\end{tabular}

\subsubsection{New York}

New York City joined the GNAFCC in 2009 and is the first city of the network [65]. The city-wide initiative for AFCC development is called Age Friendly NYC [10]. Many of New York's AFCC development and practices are incorporated in the Age Friendly NYC initiative. In the latest commission of the initiative, nearly 90 programmes cover all the eight domains of AFCC under the initiative. It makes the policy an AFCC toolkit to guide the practitioners from different sectors. The city's government integrates the concept into the city's strategy of OneNYC, which emphasises growth, sustainability, resilience and equity [66]. Age Friendly NYC is regarded as an initiative of Healthy Neighbourhood, Active Living in OneNYC [13].

New York has several characteristics, according to the government documents. (1) The municipal government has a particular department, the Department for the Aging (DFTA), to tackle issues related to older people. The department became the government leader in administrating Age Friendly NYC initiatives. (2) AFCC is developed with a broad policy integration in New York. Different government departments participate in the Age Friendly NYC and deliver specialised programmes. The commissioner of the DFTA is involved in different policymaking and administrative boards of many other government sectors. (3) Besides DFTA, the American Association of Retired Persons (AARP) is another professional and influential organization frequently involved in public decision making of different sectors. The policies and programmes of New York are summarized in Table 2. 
Table 2. New York AFCC policies and programmes.

\begin{tabular}{|c|c|}
\hline Domain & Policies and Programmes \\
\hline All eight domains & Age Friendly NYC and its programmes [10] \\
\hline $\begin{array}{l}\text { Transportation } \\
\text { Community support and health services }\end{array}$ & OneNYC [13] \\
\hline $\begin{array}{l}\text { Outdoor space and buildings } \\
\text { Housing }\end{array}$ & $\begin{array}{c}\text { Aging in Place Guide for Building Owners: } \\
\text { Recommended Age-Friendly Residential } \\
\text { Building Upgrades [67] }\end{array}$ \\
\hline Community support and health services & $\begin{array}{l}\text { The New York City Falls Prevention Coalition } \\
\text { [68] }\end{array}$ \\
\hline Respect and social inclusion & Ageless New York [69] \\
\hline $\begin{array}{c}\text { Housing } \\
\text { Respect and social inclusion } \\
\text { Community support and health services }\end{array}$ & $\begin{array}{l}\text { Public Housing Agency Annual Agency Plan } \\
\qquad[70-74]\end{array}$ \\
\hline Transportation & Vision Zero [75] \\
\hline Respect and social inclusion & Robotic Pet Pilot Program [76] \\
\hline Housing & Senior Affordable Rental Apartments $[77,78]$ \\
\hline Housing & Seniors First [79] \\
\hline $\begin{array}{c}\text { Outdoor space and buildings } \\
\text { Social participation } \\
\text { Respect and social inclusion } \\
\text { Communication and information } \\
\text { Community support and health services }\end{array}$ & $\begin{array}{c}\text { "Plan 2025": Aging Services in an Era of Rapid } \\
\text { Population Growth [80] }\end{array}$ \\
\hline $\begin{array}{l}\text { Outdoor Space and buildings } \\
\text { Respect and social inclusion } \\
\text { Community support and health services }\end{array}$ & Cool Neighbourhoods NYC [81] \\
\hline $\begin{array}{l}\text { Communication and information } \\
\text { Community support and health services }\end{array}$ & $\begin{array}{c}\text { Insurance Information Counseling and } \\
\text { Assistance Program [82] }\end{array}$ \\
\hline $\begin{array}{c}\text { Housing } \\
\text { Community support and health services }\end{array}$ & Home Energy Assistance Program [82] \\
\hline Outdoor space and buildings & CityBench [83] \\
\hline $\begin{array}{l}\text { Housing } \\
\text { Social participation }\end{array}$ & $\begin{array}{l}\text { Naturally Occurring Retirement Communities } \\
\text { [84] }\end{array}$ \\
\hline
\end{tabular}

\subsubsection{Singapore}

Singapore joined the network in 2020. The guideline policy for Singapore's AFCC development is the Action Plan for Successful Ageing developed by the Ministerial Committee on Ageing in 2015 [85]. The Action Plan for Successful Ageing has three levels: individual level, community level and city level. At the individual level, the plan stresses "longevity is opportunity" and four practical domains: lifelong employability, health and wellness, senior learning and senior volunteerism. At the community level, the plan stresses "cohesive home with intergenerational harmony" and two practical domains: community befriending and inter-generational harmony. Finally, at the city level, the plan stresses "live well and age confidently in place" and four practical domains: aged care, active ageing and assisted living, transport and research [86].

The long-term development of Singapore is the Master Plan developed by Urban Redevelopment Authority. Although there is no direct linkage between the Master Plan and the Action Plan for Successful Ageing, there is a specific theme, Liveable and Inclusive Communities in the Action Plan, which contains the consideration for older citizens and AFCC [87]. Meanwhile, the Urban Redevelopment Authority also invites Singapore citizens to build AFCC in a programme called "Plan our Future SG". In the programme, 
the authority proposed six dimensions for AFCC. The five dimensions at the neighbourhood level are safety, walkable, inclusive public transport, engaging and inclusive and a therapeutic environment. In addition, one dimension implemented in nursing homes is innovative design typologies [88].

According to the government documents of Singapore, much of the attention has been paid to retaining older residents' employability. As a result, Singapore has a very high employment rate among people aged 60 and above. The city is a good example to turn the ageing population into an impetus of urban development. Table 3 summarises the government AFCC policies and initiatives in Singapore.

Table 3. Singapore AFCC policies and programmes.

\begin{tabular}{|c|c|}
\hline Domain & Policies and Programmes \\
\hline All eight dimensions & Action Plan for Successful Ageing [89] \\
\hline $\begin{array}{l}\text { Outdoor space and buildings } \\
\text { Social participation } \\
\text { Respect and social inclusion } \\
\text { Community support and health services }\end{array}$ & Master Plan [87] \\
\hline $\begin{array}{l}\text { Civic participation and } \\
\text { employment }\end{array}$ & $\begin{array}{c}\text { WorkPro [90] (ceased) } \\
\text { Senior Worker Early Adopter Grant and } \\
\text { Part-time Re-employment Grant [91] }\end{array}$ \\
\hline Housing & Enhancement for Active Senior [92] \\
\hline Housing & Lift Upgrading Programme [92] \\
\hline $\begin{array}{l}\text { Outdoor space and buildings } \\
\text { Housing }\end{array}$ & Neighbourhood Renewal Programme [92] \\
\hline $\begin{array}{c}\text { Social participation } \\
\text { Respect and social inclusion } \\
\text { Community support and health services }\end{array}$ & Silver Hubs $[93,94]$ \\
\hline Outdoor space and buildings & $\begin{array}{l}\text { The Universal Design Guide for Public Places } \\
\text { [95] }\end{array}$ \\
\hline $\begin{array}{c}\text { Respect } \\
\text { Communication and information }\end{array}$ & Silver Infocomm Junctions [96] \\
\hline Housing & Selective En bloc Redevelopment Scheme [97] \\
\hline $\begin{array}{c}\text { Social participation } \\
\text { Respect and social inclusion } \\
\text { Civic participation and } \\
\text { employment } \\
\text { Community support and health services }\end{array}$ & PA Wellness Programme [97] \\
\hline $\begin{array}{l}\text { Civic participation and } \\
\text { employment }\end{array}$ & $\begin{array}{c}\text { Tripartite Standard on Age-Friendly Workplace } \\
\text { Practices [98] }\end{array}$ \\
\hline $\begin{array}{l}\text { Civic participation and } \\
\text { employment }\end{array}$ & Retirement and Re-employment Act [99] \\
\hline $\begin{array}{l}\text { Civic participation and } \\
\text { employment }\end{array}$ & Special Employment Credit scheme [99] \\
\hline Transportation & Silver Zone [88] \\
\hline $\begin{array}{l}\text { Civic participation and } \\
\text { employment }\end{array}$ & Job Growth Incentive [100] \\
\hline $\begin{array}{l}\text { Outdoor space and buildings } \\
\text { Community support and health services }\end{array}$ & Therapeutic Gardens [101] \\
\hline
\end{tabular}


Table 3. Cont.

\begin{tabular}{|c|c|}
\hline Domain & Policies and Programmes \\
\hline $\begin{array}{l}\text { Civic participation and } \\
\text { employment }\end{array}$ & Workfare Skills Support Scheme [102] \\
\hline $\begin{array}{l}\text { Civic participation and } \\
\text { employment }\end{array}$ & Work-Life Grants [103] \\
\hline Community support and health services & Silver Community Test-Bed Programme [104] \\
\hline $\begin{array}{l}\text { Civic participation and } \\
\text { employment }\end{array}$ & $\begin{array}{c}\text { Tripartite Guidelines on the Re-Employment of } \\
\text { Older Employees [105] }\end{array}$ \\
\hline Outdoor space and buildings & Accessibility Fund [106] \\
\hline $\begin{array}{c}\text { Housing } \\
\text { Community support and health services }\end{array}$ & Community Care Apartments [107] \\
\hline All eight domains & $\begin{array}{l}\text { Creating Senior-Friendly Communities: } \\
\text { Tips and Tools from the City for All Ages } \\
\text { Project [108] }\end{array}$ \\
\hline
\end{tabular}

\subsubsection{Hong Kong: AFCC Policy Strengths and Weaknesses by Comparison}

Compared with the other three cities, Hong Kong has the following characteristics. Firstly, the unit joining the GNAFCC is the districts in the city instead of the city. Currently, all the 18 electoral districts of Hong Kong have been accredited by the WHO to join the Network. The commitments to join the GNAFCC were from district councils under the support of the Hong Kong government and the Hong Kong Jockey Club Charities Trust. District councils are regional organisations established by the Hong Kong government to provide "advice to government on matters that affect the well-being of residents" [109]. All districts' baseline assessment and action plans are developed by coordination with the Hong Kong Jockey Club Charities Trust and four local universities [110]. In these action plans, the development focuses are clearly stated in a structuralised way which can be evaluated by systematical observation. Thus, the commitment of Hong Kong to join the Network has the following three characteristics: (1) The action plans are of high accountability. (2) The bottom-up pathway to conduct AFCC development is very close to the genuine demands of the residents. (3) As the WHO accredited all the districts, AFCC can equally benefit a wide range of older people no matter where they live.

At the city level, AFCC was put into the 2016 Policy Address [8] and the long-term urban development strategy, Hong Kong 2030+ [111]. Hong Kong stresses more on the environmental space aspect of AFCC at the city level, including barrier-free environment, outdoor spaces, and a liveable home environment $[112,113]$. The only dimension-belonging social environment is digital inclusion in the 2016 Policy Address [8]. Such preferential support is reasonable because Hong Kong has a well-spread supportive service network for older people developed under the principle of active ageing [114]. There is also broad participation of social stakeholders to support older residents [115]. Meanwhile, the spatial problems are severe, especially in the old districts where older people concentrate $[45,116]$. Thus, AFCC can be regarded as enhancing Hong Kong's active ageing policies from the built environment aspects.

According to the previous studies, financial security is a central issue of Hong Kong's policies for older people. The lack of a traditional social security system is widely mentioned as the cause of older people's poverty problems in Hong Kong. The government provides three financial assistance schemes for older residents: the Comprehensive Social Security Assistance (CSSA), Old Age Allowance (OAA) and Old Age Living Allowance (OALA). However, these financial assistance schemes are thought insufficient to solve the poverty problem [117]. There are other governmental subsidies covering transportation, housing and health services. For transportation, the government launched the Government Public Transport Fare Concession Scheme for the Elderly and Eligible Persons with Disabil- 
ities. The scheme aims to encourage older people to participate in more social activities by providing a low fare of HKD 2 per trip [118]. For housing, the government provides Public Rental Housing (PRH) for people with housing problems. According to previous studies, many PRH occupants are older people $[119,120]$. The government provides Health Care Vouchers to encourage older people to use private primary health care services [117]. Although these subsidised schemes satisfy older residents' daily demands, their emphasis on subsidising in ageing policies may exacerbate the negative societal attitude towards older people regarding them as dependent on social welfare. Some other kinds of policies may also reinforce older people's stereotypes. For instance, as a scheme to facilitate inclusive public transportation services, Transportation for All is found to concentrate on the demands of people with disability problems [121]. The policy may reinforce the stereotype of older people with low mobility. Too much reliance on this kind of policy may hinder the transformation of older people into contributors to urban development.

Some other studies also show that Hong Kong has a good policy foundation for AFCC building and facilitating the active ageing of older citizens. Generally, the term "active ageing" firstly appeared in the 1997's Policy Address of the Hong Kong Government, and the concept was put into a framework by the Elderly Commission in 2006. The framework uses seven sub-factors to specify the three pillars of active ageing and regulate individual and government's responsibility to realise active ageing in Hong Kong. These seven subfactors include (1) physical environment and (2) finance for the pillar of security; (3) retirement and part-time employment, (4) elder learning and (5) volunteering for the pillar of participation; (6) individual health maintenance and (7) ensuring a basic medical system for the pillar of health maintenance [122]. The government launched the Elder Academy Scheme to enhance older people's mental and physical well-being [122]. The government also ensures the productivity activities for older people by the Hong Kong Employment Program for Middle-Aged Workers to prevent employment-related ageing discrimination for people older than 40 years old [123]. In 2012, the government developed a series of Reference Frameworks in the Primary Care Setting, and one of these frameworks is for older people, which guides the preventive care for older people [124,125]. For financial security, re-examining the previous definition of older people's poverty, Woo et al. [126] found that the government subsidies can play the same role as the pension system from the perspective of adequacy of disposable income.

In summary, there are the three key characteristics of Hong Kong's AFCC policies:

(1) Hong Kong's AFCC development is decentralised to the district level, which should be an opportunity to make the AFCC policies closer to older residents' genuine demands. At the same time, the Hong Kong government has put the AFCC in the city's long-term development strategy. Thus, AFCC is one of the city's future development agendas and it needs to be integrated with the SUD policy agenda.

(2) Hong Kong's current AFCC policy focuses mainly on the built environment aspect. However, a comprehensive support network has already been developed for older people by the government and other non-government stakeholders under the principle of active ageing. This provides a good foundation for further developing AFCC.

(3) Some existing policies related to subsidised services may reinforce the stereotype of older residents as the burden of SUD. However, the government has already started developing more active ageing policies and paid continuous attention to active ageing, which may enhance SUD in the face of population ageing in Hong Kong.

Policy recommendations to integrate AFCC and SUD will be given based on these advantages and disadvantages in the discussion section later.

\section{Materials and Methods}

\subsection{Dataset}

The dataset used for analysis in this research comes from a published report of a PPR project named "Sustainable Planning Criteria (SPC) for Age-Friendly Precincts (AFP) in the New Development Areas (NDAs) of Hong Kong" funded by the Central Policy Unit 
of Hong Kong SAR government [24]. The project was preliminary designed to find the sustainable development criteria for age-friendly precincts. The questionnaire survey was developed through a comprehensive literature review and interviewed 21 local experts in related professions. The details of the questionnaire development have already been well stated in previous publications [24,45]. In 2014, the survey was conducted in eight selected areas in Hong Kong, including new development areas (Sha Tin, Fan Ling and Sheung Shui), the CBD (Central), urban renewal districts (Kwun Tong and Sham Shui Po), a planned cultural zone (West Kowloon) and a highly dense old area (Hung Hom). The selection covered different scenarios in Hong Kong.

To contact actual spatial users, a street-intercept method was used to capture 100 respondents from each of the areas. This method has advantages in sample coverage, response rate, completion rate, yield rate and interference rate [127]. A total of 772 out of the 800 responses were valid. In total, $39 \%$ of them were above 60 -year-old, which is higher than the overall portion in Hong Kong in 2014 [128]. However, the sample was reasonable because age-friendly development mainly aims to address the needs of the older people and to enhance their wellbeing. It is also reasonable to incorporate younger people. Firstly, age-friendly development should enhance the liveability for all ages to prevent the segment of the older population [129]. Secondly, the opinions of the younger and working population are determinants in urban planning [5]. Lastly, as younger generations are the major caregivers to their parents, younger caregivers' environmental perceptions can supplement that of the older residents $[24,130]$. Other demographic characteristics of the respondents are summarised in Table 4.

Table 4. Respondents' demographic characteristics of the dataset. Source: Summarised from [24].

\begin{tabular}{|c|c|c|}
\hline \multicolumn{2}{|r|}{ Category } & \multirow{2}{*}{$\begin{array}{c}\text { Portion } \\
50.46 \%\end{array}$} \\
\hline \multirow{12}{*}{ Education attainment } & Male & \\
\hline & Female & $49.54 \%$ \\
\hline & Below 30 & $19.43 \%$ \\
\hline & $31-40$ & $9.97 \%$ \\
\hline & $41-50$ & $11.01 \%$ \\
\hline & $51-60$ & $20.06 \%$ \\
\hline & $61-70$ & $26.17 \%$ \\
\hline & $71-80$ & $9.07 \%$ \\
\hline & Above 80 & $3.76 \%$ \\
\hline & Primary education & $19.92 \%$ \\
\hline & Secondary education & $36.36 \%$ \\
\hline & Tertiary education & $28.61 \%$ \\
\hline \multirow{8}{*}{ Occupation } & Above tertiary education & $10.92 \%$ \\
\hline & Commercial sector & $19.49 \%$ \\
\hline & Professional sector & $14.65 \%$ \\
\hline & Academic & $8.33 \%$ \\
\hline & Government & $6.72 \%$ \\
\hline & Private sector/NGO & $6.18 \%$ \\
\hline & Planning and development sector & $2.82 \%$ \\
\hline & Other (unemployed/retired/not want to say) & $41.80 \%$ \\
\hline \multirow{8}{*}{ Residing district } & Kwun Tong & $16.25 \%$ \\
\hline & Sham Shui Po & $13.00 \%$ \\
\hline & Sha Tin & $13.00 \%$ \\
\hline & Sheung Shui & $12.50 \%$ \\
\hline & Fan Ling & $9.00 \%$ \\
\hline & Central & $6.88 \%$ \\
\hline & West Kowloon & $6.13 \%$ \\
\hline & Hung Hom & $5.50 \%$ \\
\hline
\end{tabular}


Table 4. Cont.

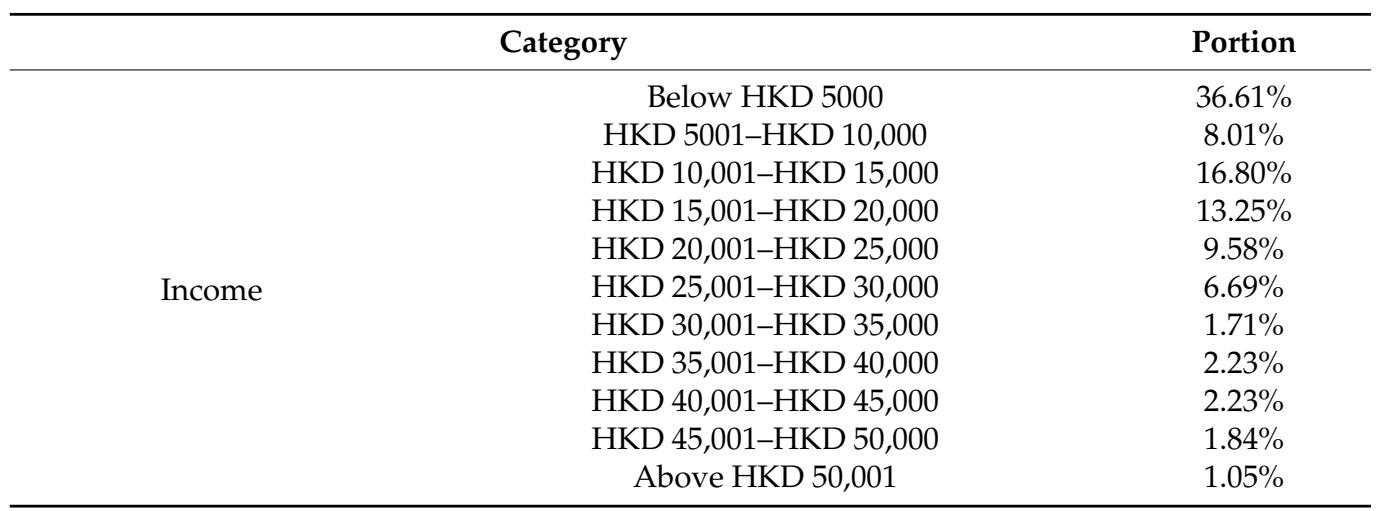

The AFCC section had seven parts in the questionnaire, namely, outdoor spaces, transportation, buildings and neighbourhood, social/civic participation, respect, communication and information and community and health services. The SUD section had three parts, namely, economic sustainability, environmental sustainability and social sustainability. There were 66 criteria in the ten parts. The respondents were asked to score their perceived importance on a five-point scale, in which one means "not important at all" and five means "very important". Our research in this paper was based on detailed analysis of the data collected in the project.

\subsection{Factor Analysis}

Among the 66 criteria, some of them may represent the same things. To simplify the strategy developed by this study, the long list of criteria needed to be dimensionally reduced into fewer representative factors. Thus, referring to the previous AFCC and SUD studies that conducted the same kind of analysis [131-134], factor analysis was used to find the representative factors for our further analysis. Factor analysis can be categorised into exploratory factor analysis (EFA) and confirmatory factor analysis (CFA). Although according to the literature review, this study developed three hypotheses, all of them were about the policy integration instead of the latent structure of the 66 AFCC and SUD criteria in this dataset. Due to a lack of presumption about the representative AFCC and SUD factors perceived by Hong Kong residents, EFA was used, as exemplified by previous studies [131].

Data were processed using IBM SPSS 23 statistical software, Chicago, IL, the United States. The extraction method was principal axis factoring (PAF). The rotation method was direct Oblimin. The KMO and Bartlett's test shown in Table 5 indicated the dataset was satisfactory to conduct PAF.

Table 5. KMO and Bartlett's test.

\begin{tabular}{ccc}
\hline \multicolumn{2}{c}{ Index } & Value \\
\hline Kaiser-Meyer-Olkin Measure of Sampling Adequacy. & 0.936 \\
Bartlett's Test of Sphericity & Approx. Chi-Square & $23,104.359$ \\
& df & 2145 \\
& Sig. & 0.000 \\
\hline
\end{tabular}

\section{Results}

\subsection{Factor Analysis}

As shown in Table A1 in Appendix A, 15 factors were extracted, accounting for $61.573 \%$ of the variation. The factor loadings are shown in Table A2 in Appendix B. The name of each factor was given according to the most related criteria of each factor. The name, naming reason and the most related criteria of each factor are shown in Table A3 in Appendix C. 
The 15 factors extracted from EFA showed a significant difference in the perceived AFCC and SUD factors between professionals (both Hong Kong local and WHO) and Hong Kong residents. These differences are shown below.

(1) A new factor contained the criteria from three categories, "outdoor spaces", "transportation" and "buildings and neighbourhoods". The most related criteria of this factor were:

- Appropriate public facilities (toilets/seats along long corridors to the public transport/venues);

- Universal accessibility (pedestrian crossings/pathways/cycle paths/parks/open spaces);

- $\quad$ Safe and comfortable facilities/environment (interior design/handrail/non-slip flooring);

- Universal access (buildings: doors/elevators; neighbourhood: ramps for wheelchair users);

- Safe and secure public spaces (hotlines for emergency rescue/well-maintained sidewalks);

- $\quad$ Safety of transportation facilities and services.

These criteria showed that safety, especially the built environment design to enhance safety, was a specific AFCC factor perceived by Hong Kong residents. Thus, this factor was named environmental safety. From the underlying criteria, the environmental safety of AFCC can be formed from three aspects: (1) A comfortable environment can enhance perceived safety for older people. (2) The universal design can enhance older people's mobility while reducing the falling risk. (3) Other security design and services should be incorporated into the built environment to reduce environmental risks for older people.

(2) The seven criteria of environmental sustainability were grouped into two factors. In the first factor, the most related criteria were:

- Zero-waste management (greater adoption of renewable energy/resource/recycling);

- Smart growth and green infrastructures;

- Urban greeneries and vegetation;

- Transit-Oriented Development (TOD).

The former three criteria were also included in the net-zero-energy building project in Ladispoli [43]. At the same time, TOD can also reduce urban energy consumption by promoting a green transportation system [135]. Thus, this factor was named the lowenergy-consumption development.

In the second factor, the most related criteria were:

- Cultural heritage/preservation;

- Redevelopment of brownfield sites and reuse of existing buildings/sites for development;

- $\quad$ Biodiversity (maritime/wetland/natural parks).

These criteria aim to conserve the local original cultural and natural factors. This aim was realized by the direct protection of cultural and natural resources on the one hand. On the other hand, the protection was achieved by preventing large-scale demolishment in the development. Thus, this factor was named conservative development.

Thus, for Hong Kong residents, environmental sustainability should be further divided into the low-energy-consumption development and conservative development.

(3) A new factor contained three criteria from "transportation" and "community and health services". These criteria included:

- Affordable public health care services;

- Accessibility and availability of public health care services;

- Affordability (user-friendly programs: HKD 2 fare using the Octopus card).

This factor well reflects Hong Kong situation presented in the literature review. Subsidised public health care and the Government Public Transport Fare Concession Scheme for the Elderly and Eligible Persons with Disabilities were two subsidised service schemes 
for older people in Hong Kong. Compared with public transportation, the subsidised public health care has a long waiting list or waiting time. This makes accessibility of public health care also very important. Thus, this factor was named subsidised public services.

(4) The rest criteria of "outdoor spaces" composed a new factor. These criteria included:

- Special customer services (special queue for elderly/care kiosk for elderly and children);

- Management and maintenance (of outdoor space);

- Quality of green environment (fresh air/nature).

This factor included three different aspects of the daily operation of outdoor spaces. Thus, the factor was named outdoor space operation.

(5) Three criteria of "transportation" formed a new factor. These criteria were:

- Travel connectivity to destinations;

- Proximity to the bus stops on foot;

- Public transport frequency and reliability.

These criteria were related to the method for older people to access public transportation. Thus, the factor was named public transportation accessibility.

(6) The nine criteria of "social/civic participation" were grouped into two factors. The first factor included the criteria of:

- Recognition of elderly contributions (certificates/banquets, etc.);

- Podium for socializing near to marketplaces (outdoor coffee shops/garden);

- Lifelong learning programs for elderly;

- Addressing isolation and intergenerational programs;

- Working and volunteering opportunities after retirement;

- Elderly participation for community planning and political leadership;

- Affordability, choices and accessibility of events.

- While the second factor included the criteria of:

- Addressing elderly discrimination in the workplace;

- Age-friendly and progressive public policy (integrated networks/minority groups support).

The first factor contained various events to solve older people's loneliness and isolation. At the same time, the second factor aimed to solve the ageism and other discrimination of vulnerable subgroups of older people. Thus, these two factors were named isolation prevention and discrimination prevention, respectfully. It also indicated that Hong Kong older residents need the policy attention to address isolation and discrimination to ensure their social and civil participation. However, the weakness is the lack of an anti-discrimination law specifically designed for older people in Hong Kong, which makes it difficult to prevent discrimination in many aspects of older people's social lives [136].

(7) Four criteria from "housing" composed a new factor. These criteria were:

- Enough housing availability for younger people in the neighbourhood;

- Management and maintenance (of housing);

- Housing options (availability and types);

- Affordability of housing.

Compared to a normal housing provision, these criteria tend to be related to public rental housing (PRH). As most occupants of PRH are older people, the older residents may need younger neighbours to improve the social integration within the community. The residents also need the scheme such as the Comprehensive Structural Investigation Programme [120] to make the housing more age-friendly. Lastly, for the scheme, options and affordability are also important for the residents. Thus, the factor was named senior housing provision.

(8) A new factor was composed of criteria from "transportation" and "housing". These criteria were: 
- Pedestrian and bus stop signages (sufficient/legible);

- Universal access in public transportations: wheelchair users and cyclists friendly;

- Age-friendly features (seats/bus stop shelters/toilets inside stations, etc.);

- Signages (sufficient/legible/voice activation: elevator buttons/placement of housing names);

- Fresh air in the buildings/rooms/neighbourhood.

This factor covers a range of built environment facilities stressed by the 2016 Policy Address [8] and Hong Kong 2030+ [11]. Even the fresh air can also be enhanced by public facilities according to Ladispoli's study [43] and the New York's policy of Cool Neighbourhoods NYC [81]. Thus, this factor is named age-friendly facilities.

(9) Lastly, four criteria of "community and health services" composed a new factor. These criteria were:

- Psychological needs for addressing isolation issues (talking/consultation);

- Promoting personal health care (wellness programs/workshops/arts/recreations/parks);

- Image grooming is good to build up elderly self-esteem;

- Need for in-home assistance for independent elderly living.

Compared with the subsidised services mentioned above, these criteria represent a new form of services that emphasise personal development in old age and keeping an active image of older people. These are also services thought to be helpful for SUD by this research. Thus, this factor was named diversified care services.

Meanwhile, social sustainability, economic sustainability, respect and communication and information were transformed by the factor analysis. Each of these four domains had a single representative factor that covered all the criteria under the domain. Thus, the residents' and the professional's perceptions were contingent on these four domains. These representative factors were named the same as they were in the questionnaire.

Six factors had negative factor loadings. These factors were subsidised public services, economic sustainability, public transportation accessibility, public senior housing provision, age-friendly facilities and diversified care services. This kind of factors actually have opposite meanings to their original name [137]. To simplify the discussion and model, this study kept the original names of these six factors. While these six factors were categorised as negative factors, the other nine factors were positive factors. In the correlation test, the direction of the correlation between a positive factor and a negative factor was reversed, otherwise the direction of the correlation was not changed.

Overall, the 15 factors were social sustainability (first factor), environmental safety (second factor), low-energy-consumption development (third factor), subsidised public services (fourth factor), economic sustainability (fifth factor), respect (sixth factor), outdoor space operation (seventh factor), public transportation accessibility (eighth factor), isolation prevention (nineth factor), public senior housing provision (tenth factor), discrimination prevention (eleventh factor), communication and information (twelfth factor), conservative development (thirteenth factor), age-friendly facilities (fourteenth factor) and diversified care services (fifteenth factor).

\subsection{Correlation Test of Factors}

If the absolute value of a correlation coefficient was above 0.3 , the two factors had a meaningful correlation $[138,139]$. The correlations between each of the fifteen factors are shown in Table 6. The meaningful correlations are highlighted. 
Table 6. Component correlation matrix.

\begin{tabular}{|c|c|c|c|c|c|c|c|c|c|c|c|c|c|c|c|}
\hline Component & 1 & 2 & 3 & 4 & 5 & 6 & 7 & 8 & 9 & 10 & 11 & 12 & 13 & 14 & 15 \\
\hline 1 & 1 & & & & & & & & & & & & & & \\
\hline 2 & 0.123 & 1 & & & & & & & & & & & & & \\
\hline 3 & 0.390 & 0.200 & 1 & & & & & & & & & & & & \\
\hline 4 & -0.101 & -0.270 & -0.190 & 1 & & & & & & & & & & & \\
\hline 5 & -0.345 & -0.130 & -0.402 & 0.137 & 1 & & & & & & & & & & \\
\hline 6 & 0.219 & 0.043 & 0.196 & -0.043 & -0.228 & 1 & & & & & & & & & \\
\hline 7 & 0.114 & 0.118 & 0.061 & 0.068 & -0.082 & 0.157 & 1 & & & & & & & & \\
\hline 8 & -0.216 & -0.305 & -0.221 & 0.174 & 0.146 & -0.164 & -0.192 & 1 & & & & & & & \\
\hline 9 & 0.255 & 0.098 & 0.198 & -0.054 & -0.322 & 0.401 & 0.153 & -0.207 & 1 & & & & & & \\
\hline 10 & -0.180 & -0.202 & -0.163 & 0.025 & 0.210 & -0.239 & -0.179 & 0.246 & -0.257 & 1 & & & & & \\
\hline 11 & 0.222 & 0.139 & 0.205 & -0.93 & -0.212 & 0.299 & 0.117 & -0.160 & 0.361 & -0.168 & 1 & & & & \\
\hline 12 & 0.236 & 0.167 & 0.210 & -0.091 & -0.223 & 0.231 & 0.056 & -0.093 & 0.215 & -0.135 & 0.179 & 1 & & & \\
\hline 13 & 0.241 & 0.066 & 0.327 & 0.051 & -0.324 & 0.177 & 0.132 & -0.014 & 0.172 & -0.105 & 0.162 & 0.217 & 1 & & \\
\hline 14 & -0.183 & -0.359 & 0.217 & 0.135 & 0.179 & -0.039 & -0.115 & 0.317 & -0.255 & 0.295 & -0.233 & -0.198 & -0.188 & 1 & \\
\hline 15 & -0.367 & 0.192 & -0.305 & 0.174 & 0.324 & -0.146 & -0.205 & 0.185 & -0.375 & 0.202 & -0.205 & -0.311 & -0.207 & 0.304 & 1 \\
\hline
\end{tabular}

Following the threshold mentioned above, all the meaningful correlations were visualised in a correlation network shown in Figure 1.

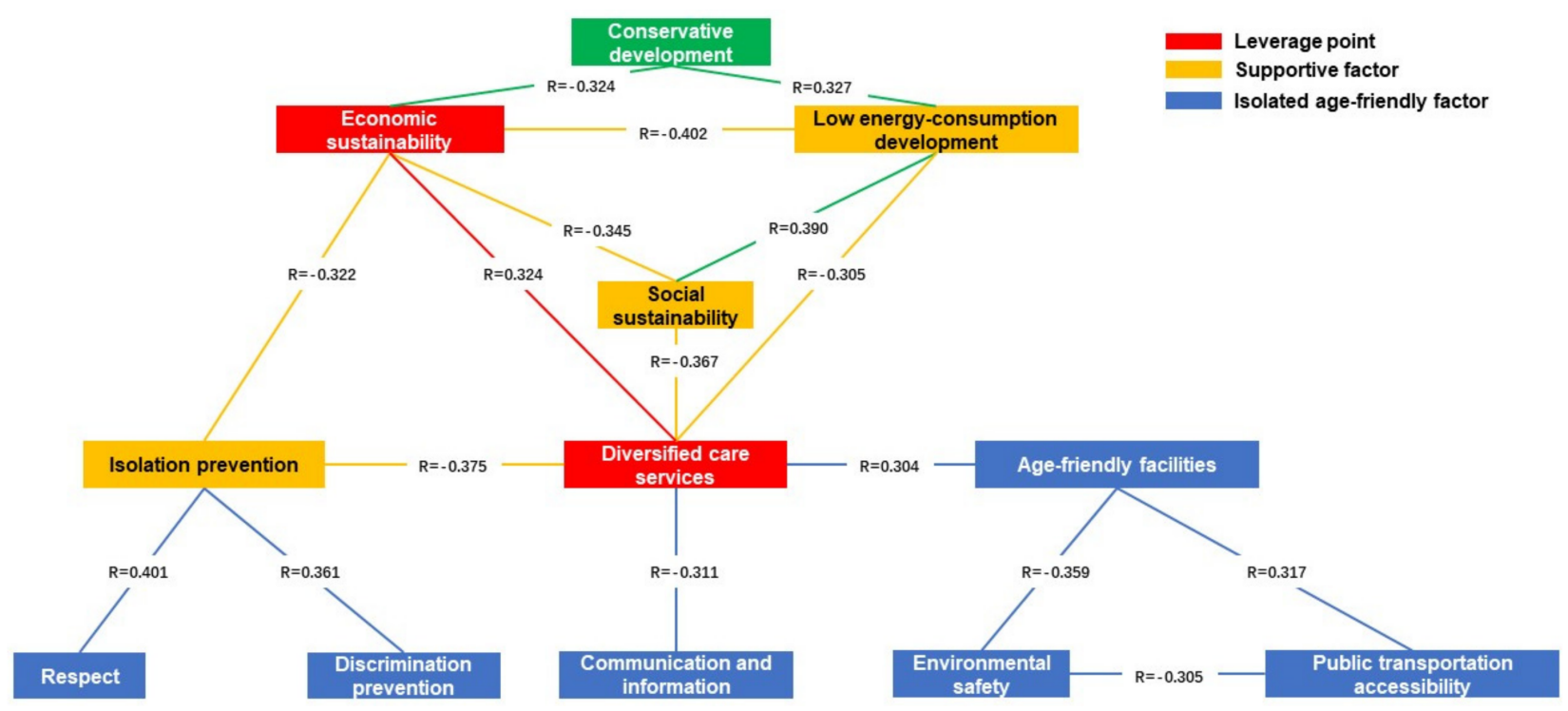

Figure 1. Correlation structure of the factors.

The correlation network (Figure 1) showed three significant points. Firstly, economic sustainability and diversified care services had the greatest number of links with other factors. They can serve as the entry points of the policy integration of SUD and AFCC. Secondly, some factors correlating with both economic sustainability and active ageing services can serve as supportive factors for the leverage points. These factors included social sustainability, low energy-consumption development and insolation prevention. Lastly, isolation prevention and diversified care services connected to other AFCC factors that need to be mainstreamed, including respect, discrimination prevention, communication and information, age-friendly facilities, public transportation accessibility and environmental safety. 


\section{Discussion}

In response to the suggestion for integrating SUD and AFCC policies [23], this study developed a stepwise strategy for government at the city level using the above correlation structure. The two entry points can be firstly developed. Then, the supportive factors can be explored. Lastly, the AFCC factors that need to be mainstreamed can be identified.

\subsection{Central Part: Building the Commercial Core}

Economic sustainability and diversified care services had the most linkages in the network, which means they were the two central nodes. Moreover, there was a correlation between these two policy factors $(r=0.324)$, which means they can be developed simultaneously to boost the whole correlation network. One solution to integrate economic sustainability and diversified care services was to develop a silver hair market. As the city ages, the transformation of elderly services from subsidised public goods to commercialised goods will create many new consumers and enhance the city's economic growth. Meanwhile, the silver hair market can supplement the government-guaranteed elderly services to provide more diversified and high-end services. The provision of elderly services is increasingly dependent on the commercial market [140]. In Hong Kong, more families seek older people services from private providers [141]. Therefore, commercialised elderly services are a practical component to revitalise the urban commercial environment. In Hong Kong, it was also proved that incorporating high-end elderly care facilities in commercial properties can benefit property owners, service providers and consumers [142], which may form a cycle of increasing benefit. From a macro aspect, public administration, social and personal services contributed to the second largest Gross Domestic Product (GDP) that increased from 2015 to 2019 in Hong Kong [143]. Making use of the silver hair market is one of the Hong Kong governments' strategies to address population ageing. The strategy was also raised in the Chief Executives' 2017 Policy Address [144]. Overall, according to the correlation network, the entry point of the policy integration between AFCC and SUD was to develop a silver hair market containing services to promote active ageing. Firstly, elderly care services should be put in the urban economic policy agenda, and the commercialised mode of elderly care provision should be supported. Secondly, policymakers should adopt policies to support elderly services by improving the profitability of services provision. This could ensure more commercial organisations participate in the development of the silver market.

\subsection{Supportive Part: Developing the Institutional Support}

According to the correlation network (Figure 1), in the second stage, policymakers should institutionalise the administrative support of the commodified care services. The support contains a physical aspect (low-energy-consumption development) and two social aspects (social sustainability and isolation prevention).

As low-energy-consumption development correlated with both economic sustainability $(r=0.402)$ and diversified care services $(r=0.305)$, low-energy-consumption development can be conducted to support the silver market. According to Fabrizio et al.'s study, the low-energy-consumption development enhances the AFCC environment mainly through providing more greenery [43]. Greenery can make the space attractive for older people to receive care services [145]. The presence of greenery can also enhance the effectiveness of care services [146,147]. Horticultural therapy even uses greenery as an instrument of health care [148]. Based on this principle, Singapore placed the therapeutic environment in its AFCC policies [88]. According to Ivan et al.'s study, the low-energy-consumption development can also improve indoor age-friendliness [44]. Some green building measures can enhance the thermal comfortability of care facilities [149]. Both pleasant natural environments and green buildings can reduce the energy consumption cost for service providers. Thus, a low-energy-consumption development can support the commodified active ageing services from two aspects. Firstly, regulations should guide and encourage the embedment of care facilities in urban greenery. Secondly, green building policies should 
pay special attention to care facilities to balance their thermal comfortability and energy consumption.

As social sustainability correlated to economic sustainability $(r=0.345)$ and diversified care services $(r=0.367)$, it facilitated the public acceptance of commodified care services. According to its most related criteria, community social sustainability represents social inclusiveness and a sense of community. Care facilities often suffer resistance from the neighbourhood residents because of the not-in-my-back-yard mentality [150]. Thus, improving neighbourhood inclusiveness can enhance the acceptance of the care facilities [151]. Meanwhile, a sense of community can facilitate residents to participate in age-friendly community development [152]. Under the land using strategy of "single site multiple uses", the Hong Kong government tried to reserve the lower floors of the buildings for some particular use, including older people's nursing homes [153]. Currently, some multigenerational housing plans have been put in a few newly developed areas [154,155]. The results of such development still need to be further observed. However, some suggestions can be tendered in advance about how social sustainability can support commodified care services in these multi-generational housing neighbourhoods. Firstly, policies should regulate enough events to foster intergenerational mutual understanding, especially covering commodified care services. Secondly, commodified care services should be set as an assessable community issue, and responsibility should be given to communities to boost local care service businesses. Lastly, policies should support some innovative service modes to serve both older and younger residents.

\subsection{Additional Part: Expanding to More AFCC Factors}

In the last stage, based on the establishment of the central and supportive parts, some more specific age-friendly development policies can be developed. These factors further enhance the integrated policy system for older people's wellbeing.

As isolation prevention correlated with both discrimination prevention $(r=0.361)$ and respect $(r=0.401)$, both the measures of countering ageism and providing a respectful atmosphere can enhance older people's participation in society. Ageism is a main institutional barrier to creating participation opportunities for older people [37], especially at the workplace. Hong Kong has delivered different measures to ensure the employability of mature employees when they are still capable of working. Tapping the talent pool of older people is one of the five strategies of Hong Kong to mitigate the negative impact brought by population ageing [156]. The financial incentive for employing older workers is also offered to the employers through the Employment Programme for the Elderly and Middle-aged from the Labour Department [157]. At the community level, a programme called the Opportunities for the Elderly Project was conducted by the Social Welfare Department of Hong Kong to engage older people in community building affairs [158]. On the other hand, older residents are frequently accused of improperly using spaces and disturbing the younger generation [159]. These criticisms deprive older people's participation. The impolite treatment can also decrease the likelihood of older people's participation [160]. The Hong Kong government also made some efforts to improve the awareness of older people's actual social image among younger generations. Under the support of the Leisure and Cultural Services Department, Hong Kong's Public Library invites older volunteers to conduct sharing workshops for children to promote intergenerational understanding [161]. The Education Bureau also put the topic of population ageing and AFCC in Secondary school's courses [162,163]. Thus, discrimination prevention and respect can be incorporated into the integrated policy system from four aspects. Firstly, a thorough review of the existing policies should eliminate institutional ageism. Secondly, stricter regulations should prohibit various forms of ageism. Thirdly, policies should ensure intergenerational activities to raise mutual understanding. Lastly, policies should regulate more public educational events to let the public learn more about older people. 
As diversified care services correlated with communication and information $(\mathrm{r}=0.311)$ and age-friendly facilities $(r=0.304)$, it was believed that information dissemination and suitable facilities can enhance both accessibility and effectiveness of care services. Older people need to know the available services. However, current information relies too much on multimedia information technology which sets a high threshold for older people's computer skills [164]. Therefore, service providers need to balance the efficiency and coverage in communication with older customers. Hong Kong government supports the service information delivery by funding a specially designed website for older people called eElderly (www.e123.hk/) (accessed on 30 July 2021). Meanwhile, information communication technology can also enhance the effectiveness of care services. With wearable applications and sensors installed in smart care facilitates, older people can obtain more responsive services [165]. The Social Welfare Department of the Hong Kong government promotes gerontechnology in care services by setting an Innovation and Technology Fund for Application in Elderly and Rehabilitation Care [166]. Age-friendly facilities can also stimulate older people to use available care services. Thus, the Labour and Welfare Bureau of the Hong Kong government conducted a programme called the Improvement Programme of Elderly Centres to improve the service quality at the community level by a physical setting enhancement [167]. Overall, communication and information and age-friendly facilities can be incorporated into the integrated policy system from four aspects. Firstly, information delivery methods should be professionally adapted for older people to ensure information coverage. Secondly, policies should facilitate innovative care services. Lastly, policies should ensure advanced age-friendly facilities are installed in older residents' homes and care facilities to enhance the attractiveness and quality of the services.

As age-friendly facilities, public transportation accessibility and environmental safety correlated to each other (age-friendly facilities-public transportation accessibility: $r=0.371$; age-friendly facilities-environmental safety: $r=0.359$; public transportation accessibilityenvironmental safety: $r=0.305)$, the tripartite relationship represented the built environment aspect of AFCC development. Public transportation and a safe environment can connect older residents to the resources outside their communities. For older people, public transportation is a vital travel mode [168]. Under the subsidised scheme provided by the Hong Kong government, the average daily public transportation trip conducted by older people reached 1,130,000 in 2018 [169]. The public transportation system can help older people reach the resources outside their walking distance [170]. To improve the accessibility to public transportation, the Hong Kong government stressed on providing covers for the pedestrians connecting to public transport intersections in the 2016 Policy Address and Policy Agenda [171]. Finally, the whole city should ensure the "last few steps towards care facilities" are safe and accessible, especially for some public transportation stops and remote service facilities in a more complex environment outside communities. It is good to see that the Transport and Housing Bureau of Hong Kong government launched "Walk in HK" to ensure older people have a safe walking environment [172].

Thus, the public transportation connection and safety and accessibility of service facilities can be incorporated in the integrated policy system from three aspects. Firstly, policies should develop age-friendliness between communities and the public transportation facilities to eliminate the "age-friendly gaps". Secondly, public transportation planning should realise inter-district shared service facilities. Lastly, policymakers should identify the facilities that are vital for older citizens outside their community and ensure their safety and accessibility.

\section{Conclusions}

Nowadays, population ageing brings worries about cities' SUD (sustainable urban development) worldwide. However, some cities have worked out their development strategy to transform older residents into contributors to their cities' long-term development by building AFCC (age-friendly cities and communities). Thus, this paper explored a three-step strategy for the policy integration of AFCC and SUD. Firstly, based on the syn- 
ergy effect between economic sustainability and diversified care services, policies should realise the commercialisation of care services through the development of the silver hair market. In the second stage, some policies should support commodified care services. Policies related to low-energy-consumption development can enhance effectiveness. Policies related to isolation prevention can expand the customer base. Policies related to social sustainability can improve neighbourhood acceptance. Lastly, more AFCC factors can be incorporated into the integrated policy system of AFCC and SUD to improve older residents' wellbeing further. Policies related to respect and discrimination prevention can ensure the effectiveness of isolation prevention. Policies related to communication and information and age-friendly facilities can enhance the accessibility and effectiveness of diversified care services. Policies related to age-friendly facilities, public transportation accessibility and environmental safety can combine the environmental triangles to ensure older people's mobility from their home to service facilities.

From a theoretical perspective, this study verified the importance of economic sustainability in the policy integration between SUD and AFCC. Thus, the first hypothesis in the literature review was verified. From a practical perspective, using Hong Kong as an example of a densely populated global city, this study provided a strategy for similar municipal government policymakers to incorporate AFCC consideration in their SUD agenda. Such policy integration can help cities take advantage of population ageing in their future development instead of being negatively influenced by the dramatically changed demographic structure. What is more, as the GNAFCC (Global Network for Age-Friendly Cities and Communities) is yet to be expanded, some potential members may need to justify how investment into AFCC development can be paid back, especially in the form of economic growth. This study gave such an example to show that AFCC can be an essential facilitator for cities' long-term development, especially from an economic perspective.

Although this study, through the correlation network analysis, provided an innovative strategy to integrate AFCC and SUD, it still has four limitations: (1) The dataset cannot fully represent the isolated older residents. It is suggested that for future study, researchers or policymakers may contact these older people through isolation prevention activities and then consult them on policy demands. (2) Some foregone correlations were missing from the correlation network, such as the correlation between age-friendly facilities and isolation prevention. A possible reason is that the survey to the public reflected a different knowledge from the professional. The different knowledge between the public and professionals also led to the second and third hypothesis not being fully verified by this study. It is because the AFCC and SUD factors extracted from the factor analysis could not respond exactly to the existing factors in the second and third hypothesis and the hypothetical model. In future studies, the survey of experts with a good understanding of the exact terms and technicalities can be conducted to improve the correlation network. (3) The correlations between SUD factors are not fully discussed, including the correlation between conservative development and economic sustainability, the correlation between conservative development and low-energy-consumption development and correlation between low-energy-consumption development and social sustainability because this research aimed to explore the strategy to integrate AFCC with SUD. These correlations can be investigated in a further study about the inner synergy effects of SUD. (4) Some factors were missing in the correlation network, including subsidised services, outdoor space operation and senior housing. Further qualitative studies can be helpful to integrate these factors into the correlation network from the perspective of the grounded theory.

Author Contributions: All authors contributed to this paper with J.H. taking the leading role. E.H.W.C. and J.H. helped design the framework. E.H.W.C., Q.K.Q. and E.H.K.Y. conducted the investigation. J.H. analysed the data and drafted the article. E.H.W.C., Q.K.Q. and E.H.K.Y. revised the article and approved the final manuscript. All authors have read and agreed to the published version of the manuscript. 
Funding: The first author acknowledges the PhD studentship offered by the Ng Wing Hong Laboratory for the Sustainable City, Department of Building and Real Estate, the Hong Kong Polytechnic University.

Institutional Review Board Statement: Not applicable.

Informed Consent Statement: Not applicable.

Data Availability Statement: Data used for analysis in this research were published by The Policy Innovation and Co-ordination Office of the Government of the Hong Kong Special Administrative Region of the People's Republic of China (Project 2013.A6.006.13A of the Public Policy Research Funding Scheme (2013-2014)). Data can be retrieved online at: www.pico.gov.hk/en/PRFS/pprreports.html (accessed on 30 July 2021). We hereby acknowledge the research team and PICO for the data.

Conflicts of Interest: The authors declare no conflict of interest.

\section{Appendix A}

Table A1. Total variance explained.

\begin{tabular}{cccccccc}
\hline \multirow{2}{*}{ Component } & \multicolumn{3}{c}{ Initial Eigen Values } & \multicolumn{2}{c}{$\begin{array}{c}\text { Extraction Sums of } \\
\text { Squared Loadings }\end{array}$} & $\begin{array}{c}\text { Rotation } \\
\text { Sums of } \\
\text { Squared } \\
\text { Loadings }\end{array}$ \\
\cline { 2 - 8 } & Total & $\begin{array}{c}\text { \% of } \\
\text { Variance }\end{array}$ & $\begin{array}{c}\text { Cumulative } \\
\text { \% }\end{array}$ & Total & $\begin{array}{c}\text { \% of } \\
\text { Variance }\end{array}$ & $\begin{array}{c}\text { Cumulative } \\
\%\end{array}$ & Total \\
\hline 1 & 16.989 & 25.741 & 25.741 & 16.505 & 25.008 & 25.008 & 6627 \\
\hline 2 & 3510 & 5318 & 31.058 & 3009 & 4559 & 29.567 & 4026 \\
\hline 3 & 3199 & 4846 & 35.905 & 2743 & 4156 & 33.723 & 6919 \\
\hline 4 & 2040 & 3091 & 38.996 & 1581 & 2395 & 36.118 & 2383 \\
\hline 5 & 1902 & 2881 & 41.877 & 1431 & 2168 & 38.286 & 7744 \\
\hline 6 & 1772 & 2684 & 44.561 & 1269 & 1922 & 40.208 & 5703 \\
\hline 7 & 1599 & 2423 & 46.985 & 1139 & 1725 & 41.934 & 2547 \\
\hline 8 & 1480 & 2243 & 49.228 & 0.988 & 1497 & 43.430 & 4451 \\
\hline 9 & 1377 & 2086 & 51.314 & 0.847 & 1284 & 44.714 & 7677 \\
\hline 10 & 1306 & 1979 & 53.293 & 0.825 & 1250 & 45.964 & 4496 \\
\hline 11 & 1227 & 1860 & 55.153 & 0.761 & 1153 & 47.117 & 4963 \\
\hline 12 & 1130 & 1711 & 56.864 & 0.633 & 0.959 & 48.077 & 4042 \\
\hline 13 & 1081 & 1638 & 58.503 & 0.604 & 0.916 & 48.992 & 4365 \\
\hline 14 & 1026 & 1555 & 60.058 & 0.565 & 0.856 & 49.848 & 5495 \\
\hline 15 & 1000 & 1515 & 61.573 & 0.507 & 0.768 & 50.615 & 7322 \\
\hline
\end{tabular}




\section{Appendix B}

Table A2. Pattern matrix (factor loading table).

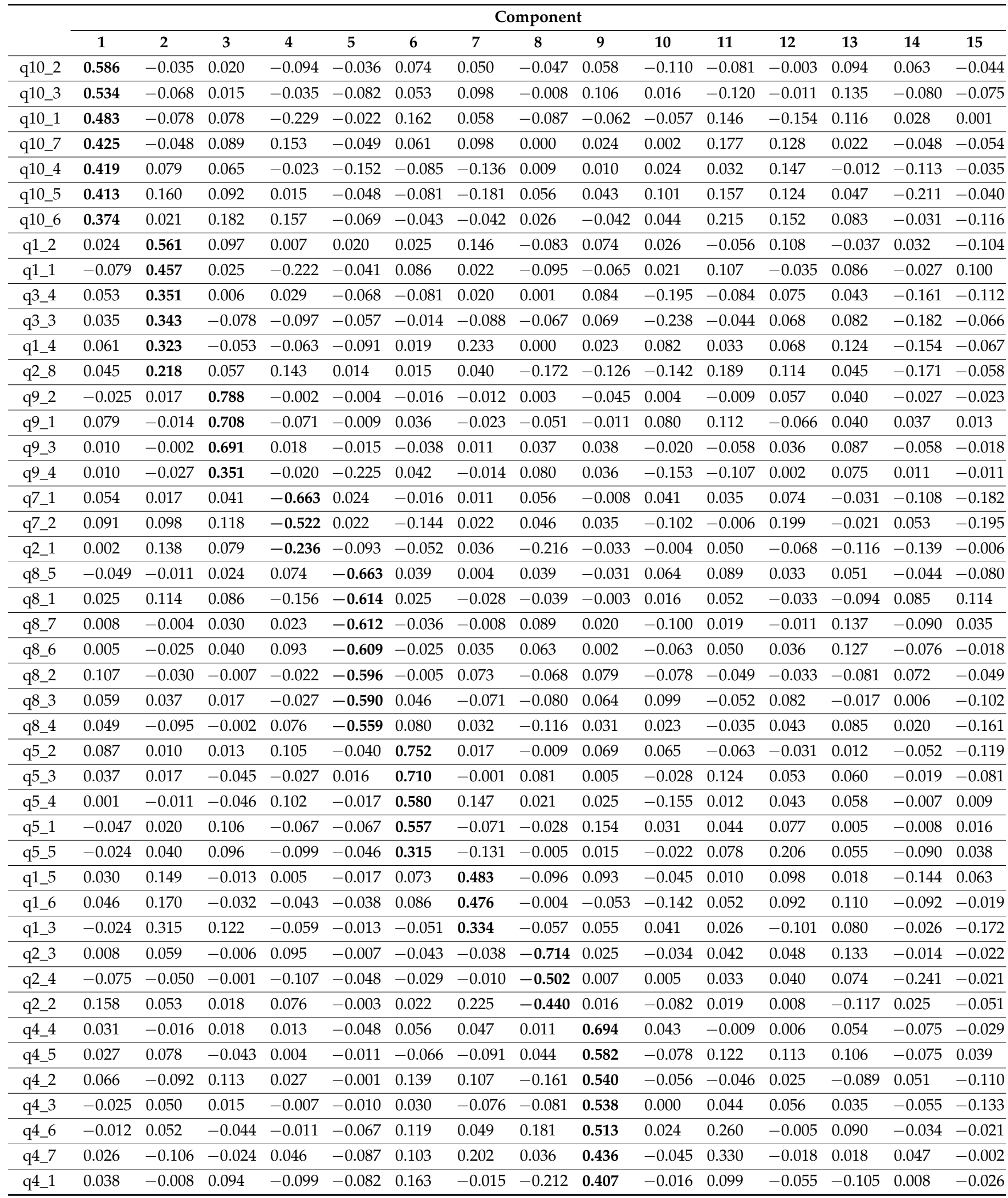


Table A2. Cont.

\begin{tabular}{|c|c|c|c|c|c|c|c|c|c|c|c|c|c|c|c|}
\hline & \multicolumn{15}{|c|}{ Compone } \\
\hline & 1 & 2 & 3 & 4 & 5 & 6 & 7 & 8 & 9 & 10 & 11 & 12 & 13 & 14 & 15 \\
\hline q3_7 & 0.033 & .151 & 0.008 & 011 & 0.112 & 0.014 & 0.166 & 14 & .060 & 0.515 & 0.041 & 024 & .086 & -0.134 & 0.0 \\
\hline q3_8 & .010 & .075 & 0.031 & -0.028 & 0.019 & -0.019 & .078 & .082 & -0.008 & 0.500 & 0.122 & .163 & .081 & -0.066 & -0.05 \\
\hline q3_1 & 138 & 169 & 0.060 & 0.014 & 0.017 & 0.177 & -0.072 & -0.110 & 0.059 & -0.497 & 0.054 & 35 & -0.103 & 0.027 & 0.031 \\
\hline q3_2 & 030 & 0.251 & .050 & -0.048 & -0.015 & 0.119 & -0.230 & .094 & 0.087 & 0.320 & -0.027 & -0.010 & -0.060 & -0.052 & -0.02 \\
\hline q4_8 & 008 & 0.064 & .035 & 0.091 & 0.012 & 0.015 & 0.054 & .061 & 0.186 & 0.074 & 0.629 & -0.036 & 0.009 & 0.009 & -0.02 \\
\hline q4_9 & 16 & 008 & -0.020 & 028 & -0.066 & 0.059 & -0.054 & .042 & 0.092 & 011 & 0.623 & 0.01 & -0.014 & 0.012 & -0.10 \\
\hline q6_2 & 040 & 18 & 0.042 & -0.101 & -0.001 & 0.037 & 0.006 & .058 & 0.072 & 000 & -0.038 & 0.593 & -0.013 & 0.030 & -0.06 \\
\hline q6_3 & 0.014 & 0.036 & 0.004 & 004 & -0.106 & 0.250 & 0.146 & 05 & 0.024 & 6 & 0.050 & 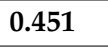 & 0.036 & 0.090 & -0.00 \\
\hline q6_1 & 105 & 0.014 & 0.171 & -0.057 & 004 & 202 & 32 & 28 & 0.050 & 1 & 0.098 & 200 & -0.057 & 026 & 0.031 \\
\hline q9_6 & 48 & 42 & 0.150 & 0.017 & 335 & 0.058 & 033 & 95 & 0.086 & 0.057 & -0.034 & 31 & 0.711 & 045 & -0.0 \\
\hline q9_7 & 49 & 58 & 0.048 & -0.020 & 89 & 0.035 & 0.004 & 50 & 0.012 & 3 & 0.025 & 0 & 0.596 & 0.075 & -0.01 \\
\hline q9_5 & 22 & 055 & 281 & 0.088 & 07 & 0.042 & 0.025 & 23 & 6 & 54 & 0.0 & 0.029 & 0.453 & -0.018 & -0.03 \\
\hline q2_6 & 53 & 5 & 5 & 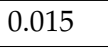 & - & 0 & 0.117 & - & 0.059 & & 0.023 & 0 & -0.093 & -0.586 & -0.06 \\
\hline q2_5 & 1 & 0. & 9 & 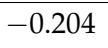 & -0 & 0. & 8 & - & 4 & 026 & 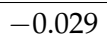 & 0.034 & 0 & -0.555 & 0.078 \\
\hline q2_7 & 81 & 0.141 & .020 & 0.099 & 8971 & 0 & 1 & -0.118 & 0. & .073 & 0.007 & 0 . & 016 & -0.434 & -0.09 \\
\hline q3_6 & 0.038 & -0.013 & 51 & -0.02 & 0. & 012 & 97 & & 4 & -0.219 & 0.063 & -0 . & -0.014 & -0.423 & -0.14 \\
\hline q3_5 & -0.020 & 0.142 & 0.129 & 0.051 & - & -0.1 & 0.105 & -0 . & 0.098 & 162 & 0.082 & -0.049 & -0.037 & -0.178 & -0.1 \\
\hline q7_5 & -0.045 & -0.029 & 0.058 & -0.057 & -0.011 & 0.114 & -0.035 & -0.052 & 0.014 & 0.040 & 0.048 & -0.017 & 0.067 & -0.038 & -0.7 \\
\hline q7_4 & 0.103 & -0.053 & -0.054 & -0.025 & -0.063 & -0.051 & 0.057 & -0.074 & 0.109 & -0.030 & -0 . & 0.044 & 0.027 & 0.061 & -0.6 \\
\hline q7_6 & 0.031 & 0.046 & 0.114 & -0.016 & 0.006 & 0.060 & -0.011 & 0.068 & 0.012 & -0.059 & 0.070 & 0. & -0.022 & -0.051 & -0.5 \\
\hline q7_3 & 0.028 & 0.096 & -0.053 & -0.211 & -0.138 & 0.038 & -0.076 & 0.016 & -0.025 & -0.021 & 0.047 & 0.050 & 0.023 & -0.018 & -0.500 \\
\hline
\end{tabular}

\section{Appendix C}

Table A3. Summary of the factors.

\begin{tabular}{|c|c|c|}
\hline & Factor and Criteria & $\begin{array}{l}\text { Factor } \\
\text { Loading }\end{array}$ \\
\hline \multicolumn{3}{|c|}{ Factor 1 Social Sustainability } \\
\hline Q10-2 & Mixed housing types for intergeneration and ageing in place & 0.586 \\
\hline Q10-3 & Social mix in community (cultural/age/gender/income) to foster city liveability & 0.534 \\
\hline Q10-1 & Community focus and community delivery (enhancing sense of place) & 0.483 \\
\hline Q10-7 & Public participation for community building and public policy consultation & 0.425 \\
\hline Q10-4 & Efficient public transportation system (easy access to work and public facilities) & 0.419 \\
\hline Q10-5 & Age-friendly features, universal design and barrier-free access & 0.413 \\
\hline Q10-6 & Low carbon communities living program & 0.374 \\
\hline \multicolumn{3}{|c|}{ Factor 2 Environmental Safety } \\
\hline Q1-2 & $\begin{array}{l}\text { Appropriate public facilities (toilets/seats along long corridors to the public } \\
\text { transport/venues) }\end{array}$ & 0.561 \\
\hline Q1-1 & $\begin{array}{l}\text { Universal accessibility (pedestrian crossings/pathways/cycle paths/parks/open } \\
\text { spaces) }\end{array}$ & 0.457 \\
\hline Q3-4 & $\begin{array}{l}\text { Safe and comfortable facilities/environment (interior design/handrail/non-slip } \\
\text { flooring) }\end{array}$ & 0.351 \\
\hline Q3-3 & $\begin{array}{l}\text { Universal access (buildings: doors/elevators; neighbourhood: ramps for } \\
\text { wheelchair users) }\end{array}$ & 0.343 \\
\hline Q1-4 & $\begin{array}{l}\text { Safe and secure public spaces (hotlines for emergency rescue/well maintained } \\
\text { sidewalks) }\end{array}$ & 0.323 \\
\hline Q2-8 & Safety of transportation facilities and services & 0.218 \\
\hline
\end{tabular}


Table A3. Cont.

\begin{tabular}{|c|c|c|}
\hline & Factor and Criteria & $\begin{array}{c}\text { Factor } \\
\text { Loading }\end{array}$ \\
\hline \multicolumn{3}{|c|}{ Factor 3 Low-Energy-Consumption Development } \\
\hline Q9-2 & $\begin{array}{c}\text { Zero-waste management (greater adoption of renewable } \\
\text { energy/resource/recycling) }\end{array}$ & 0.788 \\
\hline Q9-1 & Smart growth and green infrastructures & 0.708 \\
\hline Q9-3 & Urban greeneries and vegetation & 0.691 \\
\hline Q9-4 & Transit-Oriented Development (TOD) & 0.351 \\
\hline \multicolumn{3}{|c|}{ Factor 4 Subsidised Services } \\
\hline Q7-1 & Affordable public health care services & -0.663 \\
\hline Q7-2 & Accessibility and availability of public health care services & -0.522 \\
\hline Q2-1 & Affordability (user-friendly programs: HKD 2 fare using Octopus card) & -0.236 \\
\hline \multicolumn{3}{|c|}{ Factor 5 Economic Sustainability } \\
\hline Q8-5 & Appropriate use of resource: land and labour, etc. & -0.663 \\
\hline Q8-1 & Economic growth and employment opportunities & -0.614 \\
\hline Q8-7 & Diversity of economies & -0.612 \\
\hline Q8-6 & Promoting fair market system, financial and social equity at the workplace & -0.609 \\
\hline Q8-2 & Compact mixed-use development (residential/commercial/retail) & -0.596 \\
\hline Q8-3 & High-quality and efficient public transportation system/networks & -0.590 \\
\hline Q8-4 & Building positive city image (landmarks/visual impacts/landscape/people) & -0.559 \\
\hline \multicolumn{3}{|c|}{ Factor 6 Respect } \\
\hline Q5-2 & History/cultural heritage & 0.752 \\
\hline Q5-3 & Socializing skills/personal empowerment & 0.710 \\
\hline Q5-4 & Fashion/beauty/styling & 0.580 \\
\hline Q5-1 & Computer classes (video chat/SMS/internet) & 0.557 \\
\hline Q5-5 & Personal health care including elderly friendly exercises/sports & 0.315 \\
\hline \multicolumn{3}{|c|}{ Factor 7 Outdoor Space Operation } \\
\hline Q1-5 & $\begin{array}{l}\text { Special customer services (special queue for elderly/care kiosk for elderly and } \\
\text { children) }\end{array}$ & 0.483 \\
\hline Q1-6 & Management and maintenance (of outdoor space) & 0.476 \\
\hline Q1-3 & Quality of green environment (fresh air/nature) & 0.334 \\
\hline \multicolumn{3}{|c|}{ Factor 8 Public Transportation Accessibility } \\
\hline Q2-3 & Travel connectivity to destinations & -0.714 \\
\hline Q2-4 & Proximity to the bus stops on foot & -0.502 \\
\hline Q2-2 & Public transport frequency and reliability & -0.440 \\
\hline \multicolumn{3}{|c|}{ Factor 9 Isolation Prevention } \\
\hline Q4-4 & Recognition of elderly contributions (certificates/banquets, etc.) & 0.694 \\
\hline Q4-5 & Podium for socializing near to marketplaces (outdoor coffee shops/garden) & 0.582 \\
\hline Q4-2 & Lifelong learning programs for elderly & 0.540 \\
\hline Q4-3 & Addressing isolation and intergenerational programs & 0.538 \\
\hline Q4-6 & Working and volunteering opportunities after retirement & 0.513 \\
\hline Q4-7 & Elderly participation for community planning and political leadership & 0.436 \\
\hline Q4-1 & Affordability, choices and accessibility of events & 0.407 \\
\hline \multicolumn{3}{|c|}{ Factor 10 Senior Housing } \\
\hline Q3-7 & Enough housing availability for younger people in the neighbourhood & -0.515 \\
\hline Q3-8 & Management and maintenance (of housing) & -0.500 \\
\hline Q3-1 & Housing options (availability and types) & -0.497 \\
\hline Q3-2 & Affordability of housing & -0.320 \\
\hline \multicolumn{3}{|c|}{ Factor 11 Discrimination Prevention } \\
\hline Q4-8 & Addressing elderly discrimination in the workplace & 0.629 \\
\hline Q4-9 & $\begin{array}{c}\text { Age-friendly and progressive public policy (integrated networks/minority groups } \\
\text { support) }\end{array}$ & 0.623 \\
\hline
\end{tabular}


Table A3. Cont.

\begin{tabular}{|c|c|c|}
\hline & Factor and Criteria & $\begin{array}{c}\text { Factor } \\
\text { Loading }\end{array}$ \\
\hline \multicolumn{3}{|c|}{ Factor 12 Communication and Information } \\
\hline Q6-2 & Hearing/understanding service staff over the phone or in person & 0.593 \\
\hline Q6-3 & $\begin{array}{l}\text { Technological aids and equipment (voice activation/motion detection/learning } \\
\text { computer) }\end{array}$ & 0.451 \\
\hline Q6-1 & Printed material (brochures/menus) in legible size and format & 0.235 \\
\hline \multicolumn{3}{|c|}{ Factor 13 Conservative Development } \\
\hline Q9-6 & Cultural heritage/preservation & 0.711 \\
\hline Q9-7 & $\begin{array}{l}\begin{array}{l}\text { Redevelopment of brownfield sites and reuse of existing buildings/sites for } \\
\text { development }\end{array}\end{array}$ & 0.596 \\
\hline Q9-5 & Biodiversity (maritime/wetland/natural parks) & 0.453 \\
\hline \multicolumn{3}{|c|}{ Factor 14 Age-Friendly Facilities } \\
\hline Q2-6 & Pedestrian and bus stop signages (sufficient/legible) & -0.586 \\
\hline Q2-5 & Universal access in public transportations: wheelchair user and cyclist- friendly & -0.555 \\
\hline Q2-7 & Age-friendly features (seats/bus stop shelters/toilets inside stations, etc.) & -0.434 \\
\hline Q3-6 & $\begin{array}{c}\text { Signages (sufficient/legible/voice activation: elevator buttons/placement of } \\
\text { housing names) }\end{array}$ & -0.423 \\
\hline Q3-5 & Fresh clean air in the buildings/rooms/neighbourhood & -0.178 \\
\hline \multicolumn{3}{|c|}{ Factor 15 Diversified Care Services } \\
\hline Q7-5 & Psychological needs for addressing isolation issue (talking/consultation) & -0.733 \\
\hline Q7-4 & $\begin{array}{l}\text { Promoting personal health care (wellness } \\
\text { programs/workshops/arts/recreations/parks) }\end{array}$ & -0.644 \\
\hline Q7-6 & Image grooming is good to build up elderly self-esteem & -0.577 \\
\hline Q7-3 & Need for in-home assistance for independent living elderly & -0.500 \\
\hline
\end{tabular}

\section{References}

1. Census and Statistics Department Hong Kong Special Administrative Region. Hong Kong Population Projections 2020-2069. Available online: https:/ / www.statistics.gov.hk/pub/B1120015082020XXXXB0100.pdf (accessed on 26 July 2021).

2. Harper, S. Economic and social implications of aging societies. Science 2014, 346, 587-591. [CrossRef]

3. The Government of the Hong Kong Special Administrative Region. Report on Manpower Projection to 2027. Available online: https: / / www.lwb.gov.hk/en/other_info/mp2027_en.pdf (accessed on 26 July 2021).

4. The Government of the Hong Kong Special Administrative Region. Speech by CS at Jockey Club Age-Friendly City International Conference cum City Partnership Scheme Award Presentation Ceremony (English only) (with Photos). Available online: https: / / www.info.gov.hk/gia/general/202106/07/P2021060700344.htm (accessed on 24 June 2021).

5. Buffel, T.; Phillipson, C. Can global cities be 'Age-Friendly cities'? Urban development and ageing populations. Cities 2016, 55, 94-100. [CrossRef]

6. Joy, M. Neoliberal rationality and the age friendly cities and communities program: Reflections on the Toronto case. Cities 2021, 108, 102982. [CrossRef] [PubMed]

7. Jarzebski, M.P.; Elmqvist, T.; Gasparatos, A.; Fukushi, K.; Eckersten, S.; Haase, D.; Goodness, J.; Khoshkar, S.; Saito, O.; Takeuchi, K.; et al. Ageing and population shrinking: Implications for sustainability in the urban century. npj Urban Sustain. $2021,1,17$. [CrossRef]

8. The Government of the Hong Kong Special Administrative Region. The 2016 Policy Address Innovate for the Economy Improve Livelihood Foster Harmony Share Prosperity. Available online: https://www.policyaddress.gov.hk/2016/eng/pdf/PA2016.pdf (accessed on 26 July 2021).

9. Barrett, A. The Economic Contribution of Older Londoners. Available online: https://www.london.gov.uk/sites/default/files/ economic_contribution_of_older_londoners-1.pdf (accessed on 26 July 2021).

10. Department for the Aging. Age-Friendly NYC New Commitments for a City for All Ages. Available online: https://www1.nyc. gov/assets/dfta/downloads/pdf/publications / AgeFriendlyNYC2017.pdf (accessed on 26 July 2021).

11. Planning Department. Hong Kong 2030+ Towards a Planning Vision and Strategy Transcending 2030 Public Engagement. Available online: https:/ /www.hk2030plus.hk/document/2030+Booklet_Eng.pdf (accessed on 26 July 2021).

12. Mayor of London. Inclusive London The Mayor's Equality, Diversity and Inclusion Strategy. Available online: https://www. london.gov.uk/sites/default/ files/mayors-equality-diversity-inclusion-strategy.pdf (accessed on 26 July 2021).

13. City of New York. One New York The Plan for a Strong and Just City. Available online: http://www.nyc.gov/html/onenyc/ downloads/pdf/publications/OneNYC.pdf (accessed on 26 July 2021). 
14. World Health Organization. Active Ageing: A Policy Framework. Available online: https://apps.who.int/iris/handle/10665/67 215 (accessed on 26 July 2021).

15. Desjardins, R.; Olsen, D.S.; Midtsundstad, T. Active ageing and older learners-Skills, employability and continued learning. Eur. J. Educ. 2019, 54, 1-4. [CrossRef]

16. Phillips, J.; Walford, N.; Hockey, A.; Sparks, L. Older People, Town Centres and the Revival of the 'High Street'. Plan. Theory Pract. 2021, 22, 11-26. [CrossRef]

17. To, K.; Chong, K.H. The traditional shopping street in Tokyo as a culturally sustainable and ageing-friendly community. J. Urban Des. 2017, 22, 637-657. [CrossRef]

18. Middling, S.; Bailey, J.; Maslin-Prothero, S.; Scharf, T. Gardening and the social engagement of older people. Work. Older People 2011, 15, 112-122. [CrossRef]

19. Cho, M.; Kim, J. Coupling urban regeneration with age-friendliness: Neighborhood regeneration in Jangsu Village, Seoul. Cities 2016, 58, 107-114. [CrossRef]

20. World Health Organization. Global Age-Friendly Cities: A Guide. Available online: https://apps.who.int/iris/handle/10665/43 755 (accessed on 26 July 2021).

21. Lui, C.W.; Everingham, J.A.; Warburton, J.; Cuthill, M.; Bartlett, H. What makes a community Age-Friendly: A review of international literature. Australas. J. Ageing 2009, 28, 116-121. [CrossRef] [PubMed]

22. Buffel, T.; Phillipson, C.; Scharf, T. Ageing in urban environments: Developing 'Age-Friendly' cities. Crit. Soc. Policy 2012, 32, 597-617. [CrossRef]

23. Buffel, T.; Phillipson, C. A Manifesto for the Age-Friendly Movement: Developing a New Urban Agenda. J. Aging Soc. Policy 2018, 30, 173-192. [CrossRef] [PubMed]

24. Chan, E.H.W.; Qian, Q.K.; Lehmann, S.; Li, X. Sustainable Planning Criteria (SPC) for Age-Friendly Precincts (AFP) in the New Development Areas (NDAs) of Hong Kong; 2013.A6.006.13A; The Policy Innovation and Co-ordination Office of the Hong Kong Special Administrative Region Government: Hong Kong, China, 2015.

25. Hogl, K.; Kleinschmit, D.; Rayner, J. Achieving policy integration across fragmented policy domains: Forests, agriculture, climate and energy. Environ. Plan. C Gov. Policy 2016, 34, 399-414. [CrossRef]

26. Candel, J.J.L.; Pereira, L. Towards integrated food policy: Main challenges and steps ahead. Environ. Sci. Policy 2017, 73, 89-92. [CrossRef]

27. Bornemann, B.; Weiland, S. The UN 2030 Agenda and the Quest for Policy Integration: A Literature Review. Politics Gov. 2021, 9 , 96-107. [CrossRef]

28. Meijers, E.J.; Stead, D. Policy integration: What does it mean and how can it be achieved? A multidisciplinary review. In Proceedings of the 2004 Berlin Conference on the Human Dimensions of Global Environmental Change: Greening of PoliciesInterlinkages and Policy Integration, Berlin, Germany, 3 December 2004; pp. 1-15.

29. Massey, E.; Huitema, D. The emergence of climate change adaptation as a new field of public policy in Europe. Reg. Environ. Chang. 2016, 16, 553-564. [CrossRef]

30. Candel, J.J.L.; Biesbroek, R. Toward a processual understanding of policy integration. Policy Sci. 2016, 49, 211-231. [CrossRef]

31. O'Halloran, P.J. Assessing the integration of cross-sectoral policy issues: A case study of Canada's approach to Countering Radicalization to Violence. Policy Sci. 2021, 54, 183-208. [CrossRef]

32. Baulenas, E. She's a Rainbow: Forest and water policy and management integration in Germany, Spain and Sweden. Land Use Policy 2021, 101, 105182. [CrossRef]

33. Parsons, K.; Lang, T.; Barling, D. London's food policy: Leveraging the policy sub-system, programme and plan. Food Policy 2021, 102037. [CrossRef]

34. Sheng, R. Coordination, harmonization or prioritization in environmental policy integration: Evidence from the case in Chongming eco-island, China. J. Environ. Plan. Manag. 2021, 1-19. [CrossRef]

35. Lafferty, W.; Hovden, E. Environmental policy integration: Towards an analytical framework. Environ. Politics 2003, 12, 1-22. [CrossRef]

36. Schraven, D.; Joss, S.; de Jong, M. Past, present, future: Engagement with sustainable urban development through 35 city labels in the scientific literature 1990-2019. J. Clean. Prod. 2021, 292, 125924. [CrossRef]

37. Neal, M.B.; DeLaTorre, A.K.; Carder, P.C. Age-Friendly Portland: A University-City-Community Partnership. J. Aging Soc. Policy 2014, 26, 88-101. [CrossRef]

38. Khan, S.; Zaman, A.U. Future cities: Conceptualizing the future based on a critical examination of existing notions of cities. Cities 2018, 72, 217-225. [CrossRef]

39. Lehning, A.J.; Greenfield, E.A. Research on Age-Friendly Community Initiatives: Taking Stock and Moving Forward. J. Hous. Elder. 2017, 31, 178-192. [CrossRef]

40. Siew, R.Y.J. Assessing the readiness of sustainability reporting tools (SRTs) for an Age-Friendly built environment. J. Financ. Manag. Prop. Constr. 2016, 21, 122-136. [CrossRef]

41. Liu, S.; Wang, Y.; Zhou, D.; Kang, Y. Two-Step Floating Catchment Area Model-Based Evaluation of Community Care Facilities' Spatial Accessibility in Xi'an, China. Int. J. Environ. Res. Public Health 2020, 17, 5086. [CrossRef]

42. Zaman, A.U.; Thornton, K. Prioritization of Local Indicators for the Development of an Age-Friendly City: A Community Perspective. Urban Sci. 2018, 2, 51. [CrossRef] 
43. Cumo, F.; Curreli, F.R.; Pennacchia, E.; Piras, G.; Roversi, R. Enhancing the Urban Quality of Life: A Case Study of a Coastal City in the Metropolitan Area of Rome. In Coastal Cities and Their Sustainable Future II; Rodriguez, G.R., Brebbia, C.A., Almorza, D., Eds.; WIT Press: Ashurst, UK, 2017; Volume 170, pp. 127-137.

44. Ivan, L.; Beu, D.; van Hoof, J. Smart and Age-Friendly Cities in Romania: An Overview of Public Policy and Practice. Int. J. Environ. Res. Public Health 2020, 17, 5202. [CrossRef]

45. Qian, Q.K.; Ho, W.K.O.; Ochoa, J.J.; Chan, E.H.W. Does aging-friendly enhance sustainability? Evidence from Hong Kong. Sustain. Dev. 2019, 27, 657-668. [CrossRef]

46. Clark, K. GenPhilly: A Strategy for Improving the Sustainability of Aging in Community Initiatives. J. Aging Soc. Policy 2014, 26, 197-211. [CrossRef] [PubMed]

47. Liu, Y.; Dijst, M.; Geertman, S.; Cui, C. Social Sustainability in an Ageing Chinese Society: Towards an Integrative Conceptual Framework. Sustainability 2017, 9, 658. [CrossRef]

48. Matei, E.; Saghin, D.; Dumitrache, L.; Nae, M. Multidimensional Approach on Sustainability of Ageing in Romanian Residential Care Centres for Elders. Sustainability 2018, 10, 3336. [CrossRef]

49. Harper, S. The COVID-19 Pandemic and Older Adults: Institutionalised Ageism or Pragmatic Policy? J. Popul. Ageing 2020, 13, 419-425. [CrossRef] [PubMed]

50. World Health Organization. About the Global Network for Age-Friendly Cities and Communities. Available online: https: / / extranet.who.int/agefriendlyworld/who-network/ (accessed on 12 June 2021).

51. Globalization and World Cities (GaWC) Research Network. The World According to GaWC 2020. Available online: https: / / www.lboro.ac.uk/gawc/world2020t.html (accessed on 12 June 2021).

52. World Health Organization. London. Available online: https://extranet.who.int/agefriendlyworld/network/london-uk/ (accessed on 13 June 2021).

53. Greater London Authority. Improving Older People's Lives. Available online: https://www.london.gov.uk/what-we-do/ communities/communities-london-how-were-improving-equality/older-people-0 (accessed on 27 June 2021).

54. Tinker, A.; Ginn, J. An Age Friendly City: How Far Has London Come? Available online: https://www.london.gov.uk/sites/ default/files/an_age_friendly_city_report.pdf (accessed on 26 July 2021).

55. Greater London Authority. An Inclusive City for Older Londoners. Available online: https://www.london.gov.uk/sites/default/ files / an-inclusive-city-for-older-londoners.pdf (accessed on 26 July 2021).

56. Greater London Authority. The London Plan. Available online: https://www.london.gov.uk/what-we-do/planning/londonplan/new-london-plan/london-plan-2021 (accessed on 26 July 2021).

57. Greater London Authority. Talk London. Available online: https://www.london.gov.uk/talk-london/ (accessed on 27 June 2021).

58. Transport for London. Freedom Pass. Available online: https://tfl.gov.uk/fares/free-and-discounted-travel/freedom-pass (accessed on 27 June 2021).

59. Transport for London. 60+ London Oyster Photocard. Available online: https://tfl.gov.uk/fares/free-and-discounted-travel/60 -plus-oyster-photocard (accessed on 27 June 2021).

60. Mayor of London. Get Moving: Pilot Scheme Review. Available online: https://www.london.gov.uk/sites/default/files/gla get_moving_report_aw_2.pdf (accessed on 26 July 2021).

61. Communities and Social Policy Unit. Mi Wifi Self-evaluation-Overview. Available online: https://www.london.gov.uk/sites/ default/files/mi_wifi_self-evaluation_-_summary_29_june_2018.pdf (accessed on 26 July 2021).

62. Greater London Authority. Volunteer with Team London. Available online: https://www.london.gov.uk/what-we-do/ volunteering/volunteer-team-london (accessed on 27 June 2021).

63. Greater London Authority. Community Spaces at Risk Fund. Available online: https://www.london.gov.uk/what-we-do/artsand-culture/cultural-infrastructure-toolbox/culture-risk-0/community-spaces-risk-fund (accessed on 27 June 2021).

64. Greater London Authority. MD2314 Equality and Fairness Workplan 2018-19. Available online: https:/ /www.london.gov.uk/ decisions/md2314-equality-and-fairness-workplan-2018-19 (accessed on 27 June 2021).

65. World Health Organization. New York City. Available online: https://extranet.who.int/agefriendlyworld/network/new-yorkcity/ (accessed on 12 June 2021).

66. Boufford, J.I. Advancing an Age-Friendly NYC. J. Urban Health 2017, 94, 317-318. [CrossRef] [PubMed]

67. Department for the Aging. Aging in Place Guide for Building Owners Recommended Age-Friendly Residential Building Upgrades. Available online: https:/ / www1.nyc.gov/assets/dfta/downloads/pdf/publications / AIPGuide2016.pdf (accessed on 26 July 2021).

68. Department for the Aging. Partnerships. Available online: https://www1.nyc.gov/site/dfta/about/partnerships.page (accessed on 27 June 2021).

69. Department for the Aging. Department for The Aging Launches "Ageless New York," a First-of-Its-Kind Media Campaign to Combat Ageism in New York City. Available online: https://www1.nyc.gov/site/dfta/news-reports/press-releases/pr-dftalaunches-Ageless-New-York.page (accessed on 27 June 2021).

70. New York City Housing Authority. Final PHA Agency Plan Annual Agency Plan for Fiscal Year 2020 Five Year Agency Plan for Fiscal Years 2020-2024. Available online: https:/ / www1.nyc.gov/assets/nycha/downloads/pdf/FY20_Final_Annual_Plan_10.1 8.19.pdf (accessed on 26 July 2021). 
71. New York City Housing Authority. Final PHA Agency Plan Annual Agency Plan for Fiscal Year 2019. Available online: https://www1.nyc.gov/assets/nycha/downloads/pdf/FY19\%20Final\%20Annual\%20Plan_10.18.18.pdf (accessed on 26 July 2021).

72. New York City Housing Authority. Final PHA Agency Plan Annual Agency Plan for Fiscal Year 2018. Available online: https://www1.nyc.gov/assets/nycha/downloads/pdf/FY18-Final-Annual-Plan-101817.pdf (accessed on 26 July 2021).

73. New York City Housing Authority. Final PHA Agency Plan Annual Agency Plan for Fiscal Year 2017. Available online: https:/ /www1.nyc.gov/assets/nycha/downloads/pdf/FY2017_final_annual_plan_101816.pdf (accessed on 26 July 2021).

74. New York City Housing Authority. Final PHA Agency Plan Annual Agency Plan for Fiscal Year 2016. Available online: https://www1.nyc.gov/assets/nycha/downloads/pdf/FY16-Revised-Final-Annual-Plan-12-30-15.pdf (accessed on 26 July 2021).

75. City of New York. Mayor de Blasio Announces New Vision Zero Action Plan to Make Most Dangerous Streets Safer. Available online: https: / / www1.nyc.gov/ office-of-the-mayor/news/101-19/mayor-de-blasio-new-vision-zero-action-plan-make-mostdangerous-streets-safer\#/ 0 (accessed on 28 June 2021).

76. Department for the Aging. DFTA Joins State Robotic Pet Trial to Combat Loneliness in Older Adults. Available online: https: / / www1.nyc.gov/site/dfta/news-reports/press-releases/pr-DFTA-joins-state-robotic-pet-trial-to-combat-lonelinessin-older-adults.page (accessed on 28 June 2021).

77. City of New York. Mayor de Blasio Announces Opening of Senior Affordable Housing Development at Essex Crossing. Available online: https:/ / www1.nyc.gov/office-of-the-mayor/news/069-18/mayor-de-blasio-opening-senior-affordable-housingdevelopment-essex-crossing (accessed on 28 June 2021).

78. Housing Preservation and Development. Senior Affordable Rental Apartments. Available online: https://www1.nyc.gov/site/ hpd/services-and-information/senior-housing.page (accessed on 28 June 2021).

79. City of New York. Mayor de Blasio Doubles Planned Senior Housing to 30,000 Affordable Homes. Available online: https:/ / www1.nyc.gov/ office-of-the-mayor/news/703-17/mayor-de-blasio-doubles-planned-senior-housing-30-0 00-affordable-homes\#/0 (accessed on 29 June 2021).

80. Department for the Aging. "Plan 2025": Aging Services in an Era of Rapid Population Growth. Available online: https: / / www1.nyc.gov/assets/dfta/downloads/pdf/reports/Plan2025-092018.pdf (accessed on 26 July 2021).

81. City of New York. Cool Neighborhoods NYC A Comprehensive Approach to Keep Communities Safe in Extreme Heat. Available online: https://www1.nyc.gov/assets/orr/pdf/Cool_Neighborhoods_NYC_Report.pdf (accessed on 26 July 2021).

82. The New York City Department of Health and Mental Hygiene. Age-Friendly Primary Care. Available online: https://www1 .nyc.gov/assets/doh/downloads/pdf/chi/chi28-8.pdf (accessed on 26 July 2021).

83. New York City Department of Transportation. NYC DOT Announces $\$ 1.5 \mathrm{M}$ in New Federal Funding to Expand Citybench Program. Available online: https://www1.nyc.gov/html/dot/html/pr2015/pr15-097.shtml (accessed on 29 June 2021).

84. Queens Community District 11. Statements of Community District Needs and Community Board Budget Requests for Queens Community District 11 Fiscal Year 2018. Available online: https://www1.nyc.gov/assets/planning/download/pdf/community/ community-portal/statement_needs/qn11_statement_2018.pdf (accessed on 26 July 2021).

85. World Health Organization. Singapore. Available online: https://extranet.who.int/agefriendlyworld/network/singapore/ (accessed on 13 June 2021).

86. Ministry of Health. Key themes and Initiatives. Available online: https://www.moh.gov.sg/ifeelyoungsg/about/key-themesand-initiatives (accessed on 18 June 2021).

87. Urban Redevelopment Authority. Liveable and Inclusive Communities. Available online: https://www.ura.gov.sg/Corporate/ Planning/Master-Plan/Themes/Liveable-and-Inclusive-Communities (accessed on 30 June 2021).

88. Urban Redevelopment Authority. Designing Our Age-Friendly City. Available online: https://www.ura.gov.sg/Corporate/GetInvolved/Plan-Our-Future-SG/Innovative-Urban-Solutions / Age-Friendly-city.aspx (accessed on 30 June 2021).

89. Ministry of Health. Action Plan for Successful Ageing. Available online: https://www.moh.gov.sg/docs/librariesprovider3 /action-plan/action-plan.pdf (accessed on 26 July 2021).

90. Ministry of Manpower. Strengthening Support for Older Workers. Available online: https://www.mom.gov.sg/- / media/mom/ documents / press-releases/2019/0819-twg-ow-report.pdf (accessed on 26 July 2021).

91. Ministry of Manpower. Senior Worker Early Adopter Grant and Part-Time Re-Employment Grant. Available online: https://www.mom.gov.sg/employment-practices/schemes-for-employers-and-employees/senior-worker-early-adoptergrant-and-part-time-re-employment-grant (accessed on 30 June 2021).

92. Housing and Development Board. Public Housing in Singapore: Social Well-Being of HDB Communities and Well-Being of the Elderly. Available online: https://www.hdb.gov.sg/-/media/HDBContent/Images/CDG/Library/Library/SHS-2018 -Monograph-2---23-Apr-2021_RED.pdf (accessed on 26 July 2021).

93. National Heritage Board. Engaging Our Community. Available online: https://www.nhb.gov.sg/what-we-do/our-work/ community-engagement (accessed on 30 June 2021).

94. National Heritage Board. Silver Hubs. Available online: https://www.nhb.gov.sg/what-we-do/our-work/communityengagement/silver-hubs (accessed on 30 June 2021). 
95. Building and Construction Authority. Singapore Universal Design Week 2016: Universal Design Goes Public. Available online: https://www1.bca.gov.sg/docs/default-source/docs-corp-news-and-publications/media-releases/sudw_media_release_ 260716.pdf?sfvrsn=b807ab0e_2 (accessed on 26 July 2021).

96. Infocomm Media Development Authority. Thanks to the Silver Infocomm Junction, A Retiree Proves that It's Never Too Late for Senior Citizens to Bridge the Digital Divide. Available online: https://www.imda.gov.sg/news-and-events/impact-news/2017 /06/when-it-comes-to-digital-skills-age-is-just-a-number (accessed on 30 June 2021).

97. Centre for Liveable Cities. Towards Ageing Well: Planning a Future-Ready Singapore. Available online: https://www.clc.gov.sg/ research-publications/publications/urban-systems-studies/view/towards-ageing-well-planning-a-future-ready-singapore (accessed on 26 July 2021).

98. Ministry of Manpower. Opening Speech at TAFEP Conference for Fair and Progressive Employment Practices 2018. Available online: https:/ / www.mom.gov.sg/newsroom/speeches /2018/0427-speech-by-mrs-josephine-teo-second-minister-formanpower-at-the-tafep-conference-on-fair-and-progressive-employment-practices-2018 (accessed on 30 June 2021).

99. Ministry of Manpower. Can Withdraw at Least \$5,000 upon Reaching Age of 55. Available online: https://www.mom.gov.sg/ newsroom/press-replies/2013/can-withdraw-at-least-5000-upon-reaching-age-of (accessed on 30 June 2021).

100. Ministry of Manpower. Laws Part of A Multi-Pronged Approach to Employment Issues. Available online: https://www.mom. gov.sg/newsroom/press-replies/2020/1105-laws-part-of-a-multi-pronged-approach-to-employment-issues (accessed on 30 June 2021).

101. Urban Redevelopment Authority. Speech by Mr Zaqy Mohamad, Minister of State for Manpower and National Development, at the Launch of the "Designing Our Age-Friendly City" Urban Lab Exhibition. Available online: https://www.ura.gov.sg/ Corporate/Media-Room/Speeches/speech19-44 (accessed on 30 June 2021).

102. Ministry of Manpower. Speech at Age Friendly Workforce Asia Conference. Available online: https://www.mom.gov.sg/ newsroom/speeches/2011/speech-by-mr-tan-chuanjin-minister-of-state-for-manpower-and-national-development-at-theAge-Friendly-workforce-asia-conference-03-november-2011-915-am-level-7-auditorium-ntuc-centre-one-marina-boulevard (accessed on 30 June 2021).

103. Ministry of Manpower. No Link between Retirement Age and CPF Payout Eligibility Age. Available online: https://www.mom. gov.sg/newsroom/press-replies / 2019/0411-no-link-between-retirement-age-and-cpf-payout-eligibility-age (accessed on 30 June 2021).

104. Government of Singapore. Speech by Mr Lim Boon Heng, Minister for Prime Minister's Office, at Committee of Supply 2009,06 February 2009, 3:30 am at Parliament. Available online: https://www.nas.gov.sg/archivesonline/data/pdfdoc/20090213001.htm (accessed on 30 June 2021).

105. Ministry of Manpower. Tripartite Guidelines on the Re-Employment of Older Employees. Available online: https://www.mom. gov.sg/-/media/mom/documents/employment-practices / guidelines/tripartite-guidelines-on-re-employment-of-olderemployees.pdf (accessed on 26 July 2021).

106. Building and Construction Authority. The Accessibility Fund: Towards a Friendly Built Environment. Available online: https: / / www1.bca.gov.sg/docs/default-source/universaldesign/af_flyer2017_final.pdf?sfvrsn=eb04d085_4 (accessed on 26 July 2021).

107. Ministry of National Development. Speech by MOS Tan Kiat How at the Singapore University of Social Sciences Webinar on "Creating an Age-Friendly Environment and Community". Available online: https://www.mnd.gov.sg/newsroom/speeches/ view / speech-by-mos-tan-kiat-how-at-the-singapore-university-of-social-sciences-webinar-on-creating-an-Age-Friendlyenvironment-and-community (accessed on 30 June 2021).

108. Civil Service College. Positive Ageing: How Can We Make It Happen? Available online: https:/ /www.csc.gov.sg/articles/ positive-ageing-how-can-we-make-it-happen (accessed on 30 June 2021).

109. The Government of the Hong Kong Special Administrative Region. Government Structure. Available online: https://www.gov. $\mathrm{hk}$ /en/about/govdirectory/govstructure.htm (accessed on 30 June 2021).

110. Jockey Club Age-Friendly City Project. Project Components Baseline Assessment and Action Plans. Available online: https:/ / www.jcafc.hk/en/Project-Components/Comprehensive-Support-Scheme-For-Districts/Baseline-Assessment-AndAction-Plans.html (accessed on 19 June 2021).

111. Planning Department. An Inclusive and Supportive City for All Ages. Available online: https://www.hk2030plus.hk/document/ An\%20Inclusive\%20and\%20Supportive\%20City\%20for\%20All\%20Ages_Eng.pdf (accessed on 26 July 2021).

112. Sun, Y.; Chao, T.-Y.; Woo, J.; Au, D.W.H. An institutional perspective of "Glocalization" in two Asian tigers: The "Structure-Agent-Strategy" of building an Age-Friendly city. Habitat Int. 2017, 59, 101-109. [CrossRef]

113. Au, A.M.L.; Chan, S.C.Y.; Yip, H.M.; Kwok, J.Y.C.; Lai, K.Y.; Leung, K.M.; Lee, A.L.F.; Lai, D.W.L.; Tsien, T.; Lai, S.M.K. AgeFriendliness and Life Satisfaction of Young-Old and Old-Old in Hong Kong. Curr. Gerontol. Geriatr. Res. 2017, $2017,6215917$. [CrossRef] [PubMed]

114. Social Welfare Department. Hong Kong: The Facts—Social Welfare. Available online: https://www.gov.hk/en/about/abouthk/ factsheets/docs/social_welfare.pdf (accessed on 26 July 2021).

115. Kwan, C.; Tam, H.C. Ageing in Place in Disaster Prone Rural Coastal Communities: A Case Study of Tai O Village in Hong Kong. Sustainability 2021, 13, 4618. [CrossRef] 
116. Sun, Y.; Fang, Y.; Yung, E.H.K.; Chao, T.Y.S.; Chan, E.H.W. Investigating the Links between Environment and Older People's Place Attachment in Densely Populated Urban Areas. Landsc. Urban Plan. 2020, 203, 103897. [CrossRef]

117. Bai, X. Hong Kong Chinese aging adults voice financial care expectations in changing family and sociocultural contexts: Implications for policy and services. J. Aging Soc. Policy 2019, 31, 415-444. [CrossRef]

118. Yang, L. Modeling the mobility choices of older people in a transit-oriented city: Policy insights. Habitat Int. 2018, 76, 10-18. [CrossRef]

119. Jayantha, W.M.; Qian, Q.K.; Yi, C.O. Applicability of 'Aging in Place' in redeveloped public rental housing estates in Hong Kong. Cities 2018, 83, 140-151. [CrossRef]

120. Wadu Mesthrige, J.; Cheung, S.L. Critical evaluation of 'ageing in place' in redeveloped public rental housing estates in Hong Kong. Ageing Soc. 2020, 40, 2006-2039. [CrossRef]

121. Szeto, W.Y.; Yang, L.; Wong, R.C.P.; Li, Y.C.; Wong, S.C. Spatio-temporal travel characteristics of the elderly in an ageing society. Travel Behav. Soc. 2017, 9, 10-20. [CrossRef]

122. Chan, A.C.M.; Cao, T. Age-Friendly Neighbourhoods as Civic Participation: Implementation of an Active Ageing Policy in Hong Kong. J. Soc. Work Pract. 2015, 29, 53-68. [CrossRef]

123. Yeung, D.Y.; Zhou, X.; Chong, S. Perceived age discrimination in the workplace: The mediating roles of job resources and demands. J. Manag. Psychol. 2021, 36, 505-519. [CrossRef]

124. Woo, J.; Mak, B.; Yeung, F. Age-Friendly Primary Health Care: An Assessment of Current Service Provision for Older Adults in Hong Kong. Health Serv. Insights 2013, 6, 69-77. [CrossRef] [PubMed]

125. Food and Health Bureau. Preventive Care for Older Adults. Available online: https://www.fhb.gov.hk/pho/rfs/english/ reference_framework/pre_care_for_older_adults.html (accessed on 18 June 2021).

126. Woo, J.; Yu, R.; Cheung, K.; Lai, E.T.C. How Much Money Is Enough? Poverty and Health in Older People. J. Nutr. Health Aging 2020, 24, 1111-1115. [CrossRef]

127. Miller, K.W.; Wilder, L.B.; Stillman, F.A.; Becker, D.M. The feasibility of a street-intercept survey method in an African-American community. Am. J. Public Health 1997, 87, 655-658. [CrossRef] [PubMed]

128. Census and Statistics Department Hong Kong Special Administrative Region. Hong Kong Population Projections 2015-2064. Available online: https:/ / www.statistics.gov.hk/pub/B1120015062015XXXXB0100.pdf (accessed on 26 July 2021).

129. Tang, J.Y.M.; Chui, C.H.K.; Lou, V.W.Q.; Chiu, R.L.H.; Kwok, R.; Tse, M.; Leung, A.Y.M.; Chau, P.H.; Lum, T.Y.S. The Contribution of Sense of Community to the Association Between Age-Friendly Built Environment and Health in a High-Density City: A Cross-Sectional Study of Middle-Aged and Older Adults in Hong Kong. J. Appl. Gerontol. 2021, 0733464821991298. [CrossRef]

130. Kwok, H.K. The Son Also Acts as Major Caregiver to Elderly Parents:A Study of the Sandwich Generation in Hong Kong. Curr. Sociol. 2006, 54, 257-272. [CrossRef]

131. Smith, R.J.; Lehning, A.J.; Dunkle, R.E. Conceptualizing Age-Friendly Community Characteristics in a Sample of Urban Elders: An Exploratory Factor Analysis. J. Gerontol. Soc. Work 2013, 56, 90-111. [CrossRef] [PubMed]

132. Lai, M.M.; Lein, S.Y.; Lau, S.H.; Lai, M.L. Modeling Age-Friendly Environment, Active Aging, and Social Connectedness in an Emerging Asian Economy. J. Aging Res. 2016, 2016, 2052380. [CrossRef]

133. Levasseur, M.; Dubois, M.F.; Généreux, M.; Menec, V.; Raina, P.; Roy, M.; Gabaude, C.; Couturier, Y.; St-Pierre, C. Capturing how Age-Friendly communities foster positive health, social participation and health equity: A study protocol of key components and processes that promote population health in aging Canadians. BMC Public Health 2017, 17, 502. [CrossRef] [PubMed]

134. Lee, K.L.G. Sustainable Urban Renewal Model for A High Density City: Hong Kong. Ph.D. Dissertation, Hong Kong Polytechnic University, Hong Kong, China, 2009.

135. Hasibuan, H.S.; Soemardi, T.P.; Koestoer, R.; Moersidik, S. The Role of Transit Oriented Development in Constructing Urban Environment Sustainability, the Case of Jabodetabek, Indonesia. Procedia Environ. Sci. 2014, 20, 622-631. [CrossRef]

136. Equal Opportunities Commission. The EOC Announces Findings of the Exploratory Study on Age Discrimination in Employment. Available online: https:/ / www.eoc.org.hk/eoc/GraphicsFolder/ShowContent.aspx?ItemID=13520 (accessed on 26 June 2021).

137. De Vaus, D.A. Surveys in Social Research, 5th ed.; Routledge: London, UK, 2002.

138. Field, A.P. Discovering Statistics Using IBM SPSS Statistics and Sex and Drugs and Rock 'N' Roll, 4th ed.; Sage: London, UK, 2013.

139. Olsson, D.; Gericke, N.; Sass, W.; Boeve-de Pauw, J. Self-perceived action competence for sustainability: The theoretical grounding and empirical validation of a novel research instrument. Environ. Educ. Res. 2020, 26, 742-760. [CrossRef]

140. Schwiter, K.; Berndt, C.; Truong, J. Neoliberal austerity and the marketisation of elderly care. Soc. Cult. Geogr. 2018, 19, 379-399. [CrossRef]

141. Leung, V.W.Y.; Lam, C.M.; Liang, Y. Parents' Expectations of Familial Elder Care under the Neoliberal Hong Kong Society. J. Fam. Issues 2020, 41, 437-459. [CrossRef]

142. Kwok, E. Hong Kong's Affluent "Silver Seniors" Create Gap in the Market for High-End Elderly Homes. Available online: https:/ / www.jll.com.hk/en/trends-and-insights/cities/silver-seniors-create-market-for-high-end-hk-elderly-homes (accessed on 26 June 2021).

143. Census and Statistics Department Hong Kong Special Administrative Region. Table 36: Gross Domestic Product (GDP) by Major Economic Activity-Percentage Contribution to GDP at Basic Prices. Available online: https://www.censtatd.gov.hk/en/web_ table.html?id=36 (accessed on 26 July 2021). 
144. The Government of the Hong Kong Special Administrative Region. The Chief Executive's 2017 Policy Address We Connect for Hope and Happiness. Available online: https:/ /www.policyaddress.gov.hk/2017/eng/pdf/PA2017.pdf (accessed on 26 July 2021).

145. Liu, G.; Yap, P.; Wong, G.H.Z.; Xiao Wei, H.; Chye Hua, E. Day Care Centers for Seniors in Singapore: Looking Back and Looking Ahead. J. Am. Med. Dir. Assoc. 2015, 16, 630.e7-630.e11. [CrossRef]

146. Carver, A.; Lorenzon, A.; Veitch, J.; Macleod, A.; Sugiyama, T. Is greenery associated with mental health among residents of aged care facilities? A systematic search and narrative review. Aging Ment. Health 2020, 24, 1-7. [CrossRef]

147. Kopp, J.; Frajer, J.; Lehnert, M.; Kohout, M.; Ježek, J. Integrating Concepts of Blue-green Infrastructure to Support Multidisciplinary Planning of Sustainable Cities. Probl. Ekorozwoju 2021, 16, 137-146. [CrossRef]

148. Jarrott, S.E.; Kwack, H.R.; Relf, D. An Observational Assessment of a Dementia-specific Horticultural Therapy Program. Horttechnology 2002, 12, 403-410. [CrossRef]

149. Mendes, A.; Bonassi, S.; Aguiar, L.; Pereira, C.; Neves, P.; Silva, S.; Mendes, D.; Guimarães, L.; Moroni, R.; Teixeira, J.P. Indoor air quality and thermal comfort in elderly care centers. Urban Clim. 2015, 14, 486-501. [CrossRef]

150. Hoffman, A.K.; Landon, J.A. Zoning and the Aging Population: Are Residential Communities Zoning Elder Care Out? Urban Lawyer 2012, 44, 629-645.

151. Buffel, T.; de Backer, F.; Peeters, J.; Phillipson, C.; Reina, V.R.; Kindekens, A.; de Donder, L.; Lombaerts, K. Promoting Sustainable Communities through Intergenerational Practice. Procedia Soc. Behav. Sci. 2014, 116, 1785-1791. [CrossRef]

152. McCrillis, E.; Skinner, M.W.; Colibaba, A. Developing rural insights for building Age-Friendly communities. J. Rural Stud. 2021, 81, 336-344. [CrossRef]

153. The Government of the Hong Kong Special Administrative Region. LCQ6: Restriction on Height above the Ground Floor Imposed on Residential Care Homes for the Elderly. Available online: https://www.info.gov.hk/gia/general/201805/02/P20180 50200803.htm (accessed on 3 July 2021).

154. Planning Department. Application for Permission under Section 16 of the Town Planning Ordinance Application No. A/YLNSW/274. Available online: https:/ / www.info.gov.hk/tpb/en/papers/RNTPC/FSYLE/A-YL-NSW-274/A_YL-NSW_274_ Mainpaper.pdf (accessed on 26 July 2021).

155. Li, S. Hong Kong developers kick off multigeneration housing projects for the elderly to live in proximity to their families. South China Morning Post, 7 April 2021.

156. The Government of the Hong Kong Special Administrative Region. Let's Tackle the Challenges ... . Available online: https: / / www.hkpopulation.gov.hk/eng/tackle.html (accessed on 3 July 2021).

157. Chan, D.; Yip, D. Elderly Employment: Latest Developments in Hong Kong and Policies in International Perspective. Available online: https:/ / www.hkeconomy.gov.hk/en/pdf/el/el-2019-10.pdf (accessed on 26 July 2021).

158. Elderly Commission. Elderly Commission Minutes of the 84th Meeting. Available online: https:/ /www.elderlycommission.gov. hk/en/download/meeting/Min_e_84_16\%20July\%202015\%20(final).pdf (accessed on 26 July 2021).

159. Zhu, X.; Li, C. A phenomenological exploration of the square dance among the Chinese elderly in urbanised communities. Learn. Cult. Soc. Interact. 2021, 28, 100494. [CrossRef]

160. Brooks-Cleator, L.A.; Giles, A.R.; Flaherty, M. Community-level factors that contribute to First Nations and Inuit older adults feeling supported to age well in a Canadian city. J. Aging Stud. 2019, 48, 50-59. [CrossRef] [PubMed]

161. Leisure and Cultural Services Department. Annual Report 2017-2018. Available online: https://www.lcsd.gov.hk/en/common/ pdf/annual_report_1718_en.pdf (accessed on 26 July 2021).

162. Education Bureau. S2 Topic 8 Hong Kong Social Problems-The Ageing Population. Available online: https://www.edb.gov. hk/attachment/en/edu-system/primary-secondary/applicable-to-secondary/moi/support-and-resources/personal-socialand-humanities-education-secondary-1-to-3/s2\%20topic\%208\%20hk\%20socail\%20problem\%20-ageing\%20population.pdf (accessed on 26 July 2021).

163. Education Bureau. Community Study Series Learning Resources Theme (2): Barrier-Free Community. Available online: https:/ / www.edb.gov.hk/attachment/en/curriculum-development/kla/pshe/references-and-resources/life-and-society / life-wide/cs_2_barrier_free_e.pdf (accessed on 26 July 2021).

164. Vukelic, M.; Cizmic, S.; Jankovic, D.; Vidanovic, B.; Petrovic, I.B. Older People as Digital Newcomers: From Evidence to Intervention Proposal. In Proceedings of the 6th International Conference on Human-Computer Interaction, Copenhagen, Denmark, 19-24 July 2020; Springer: Cham, Switzerland, 2020; pp. 341-350.

165. Tun, S.Y.Y.; Madanian, S.; Mirza, F. Internet of things (IoT) applications for elderly care: A reflective review. Aging Clin. Exp. Res. 2021, 33, 855-867. [CrossRef] [PubMed]

166. The Government of the Hong Kong Special Administrative Region. Speech by S for IT at Award Presentation Ceremony of Jockey Club Age-Friendly City Partnership Scheme (English only). Available online: https:/ /www.info.gov.hk/gia/general/201906/05/ P2019060500417.htm (accessed on 3 July 2021).

167. The Government of the Hong Kong Special Administrative Region. The Hong Kong Special Administrative Region of the People's Republic of China The Chief Executive's 2017 Policy Address Policy Agenda. Available online: https:/ / www.policyaddress.gov. hk/2017/eng/pdf/Agenda.pdf (accessed on 26 July 2021).

168. Rosenbloom, S. Meeting Transportation Needs in an Aging-Friendly Community. Generations 2009, 33, $33-43$. 
169. The Government of the Hong Kong Special Administrative Region. Speech by CS at Opening Ceremony of Gerontech and Innovation Expo Cum Summit (English only) (with Photos/Video). Available online: https://www.info.gov.hk/gia/general/20 1811/22/P2018112200421.htm (accessed on 3 July 2021).

170. Loukaitou-Sideris, A.; Wachs, M.; Pinski, M. Toward a Richer Picture of the Mobility Needs of Older Americans. J. Am. Plan. Assoc. 2019, 85, 482-500. [CrossRef]

171. Transport and Housing Bureau. Legislative Council Panel on Transport 2016 Policy Agenda Transport-Related Policy Initiatives of the Transport and Housing Bureau. Available online: https:/ /www.thb.gov.hk/eng/policy/transport/policy/2016/2016tp-e.pdf (accessed on 26 July 2021).

172. Transport and Housing Bureau. Legislative Council Panel on Transport 2017 Policy Address and Policy Agenda Transport-related Policy Initiatives of the Transport and Housing Bureau. Available online: https://www.thb.gov.hk/eng/policy/transport/ policy / 2017/tp20170120cb4-413-3-e.pdf (accessed on 26 July 2021). 